\title{
Phosphorus Speciation in Long-Term Drained and Rewetted Peatlands of Northern Germany
}

\author{
Wakene Negassa ${ }^{1, * \mathbb{D}}$, Dirk Michalik ${ }^{2,3}$, Wantana Klysubun ${ }^{4}$ and Peter Leinweber ${ }^{1,5}$ \\ 1 Faculty of Agriculture and Environmental Sciences, University of Rostock, Justus-von-Liebig-Weg 6, \\ 18051 Rostock, Germany; peter.leinweber@uni-rostock.de \\ 2 Institute of Chemistry, University of Rostock, Albert-Einstein-Straße 3a, 18059 Rostock, Germany; \\ dirk.michalik@uni-rostock.de \\ 3 Leibniz Institute for Catalysis, Albert-Einstein-Straße 29a, 18059 Rostock, Germany \\ 4 Synchrotron Light Research Institute, Muang District, 111 Moo 6, University Avenue, Nakhon Ratchasima \\ 30000, Thailand; wantana@slri.or.th \\ 5 University of Rostock, Interdisciplinary Faculty, Department Life, Light and Matter, Albert-Einstein Str. 25, \\ 18051 Rostock, Germany \\ * Correspondence: wakene.chewaka@uni-rostock.de
}

Received: 29 November 2019; Accepted: 5 February 2020; Published: 10 February 2020

check for updates

\begin{abstract}
Previous studies, conducted at the inception of rewetting degraded peatlands, reported that rewetting increased phosphorus $(\mathrm{P})$ mobilization but long-term effects of rewetting on the soil $\mathrm{P}$ status are unknown. The objectives of this study were to (i) characterize $P$ in the surface and subsurface horizons of long-term drained and rewetted percolation mires, forest, and coastal peatlands and (ii) examine the influence of drainage and rewetting on P speciation and distributions using wet-chemical and advanced spectroscopic analyses. The total $\mathrm{P}$ was significantly $(\mathrm{p}<0.05)$ different at the surface horizons. The total concentration of P ranged from 1022 to $2320 \mathrm{mg} \mathrm{kg}-1$ in the surface horizons and decreased by a factor of two to five to the deepest horizons. Results of the chemical, solution 31P nuclear magnetic resonance (NMR), and P K-edge X-ray absorption near-edge structure (XANES) indicated that the major proportions of total $\mathrm{P}$ were organic $\mathrm{P}(\mathrm{Po})$. In the same peatland types, the relative proportions of $\mathrm{Po}$ and stable $\mathrm{P}$ fractions were lower in the drained than in the rewetted peatland. The results indicate that long-term rewetting not only locks $\mathrm{P}$ in organic matter but also transforms labile $\mathrm{P}$ to stable $\mathrm{P}$ fractions at the surface horizons of the different peatland types.
\end{abstract}

Keywords: Hedley sequential fractionation; inorganic phosphorus; organic phosphorus; P K XANES; phosphorus fractions; solution ${ }^{31} \mathrm{P}$ NMR

\section{Introduction}

Peatlands can be a sink, source, and transformer of $\mathrm{P}$, other essential plant nutrients, and pollutants that originate from agricultural soils, industrial, and urban waste [1]. Drainage is one of the principal management practices that enabled an agricultural use of peatlands. However, drainage has contributed to peatland degradation in Europe and worldwide [2,3]. Such degraded peatlands can be a source of $P$ that contributes to freshwater eutrophication by enhancing the growth of algae and other aquatic plants [4].

Returning a peatland into carbon $(C)$ accumulating state requires rewetting of degraded peatlands by raising the water table that facilitates the recolonization of peat-forming plant communities [5]. On the other hand, rewetting drained peatlands was reported to mobilize $\mathrm{P}$ as compared to pristine peatlands in incubation and leaching experiments [6,7]. Similarly, rewetting agriculturally influenced peatlands increased the concentrations of soluble P as shown in a study across Europe [4]. However, high P mobilization at the inception of rewetting agriculturally influenced peatland perhaps can be transient since soluble $\mathrm{P}$ is 
dynamic and may be taken up by microbes and plants, lost by leaching and drainage, and form secondary $\mathrm{P}$ minerals $[8,9]$. Thus, a complete account of $\mathrm{P}$ species is required to predict the $\mathrm{P}$ mobilization or stabilization potential in long-term drained and rewetted peatland types [10,11].

Phosphorus transformations can vary according to management practices, peatland types, topographic positions, historic, and current land use types [12]. For instance, when a peat soil predominated by redox-sensitive elements is rewetted, $\mathrm{P}$ mobilization and release of soluble $\mathrm{P}$ species can occur by the reductive dissolution of binding partners of phosphate, especially pedogenic Fe-(oxy)hydroxides $[6,13,14]$. However, there is no information on the influence of long-term drainage and rewetting of percolation mires, forest, and coastal peatlands.

Traditional wet chemical and advanced spectroscopic analytical techniques such as sequential $\mathrm{P}$ fractionation, solution ${ }^{31} \mathrm{P}$ nuclear magnetic resonance (NMR), and $\mathrm{X}$-ray absorption near edge structure (XANES) spectroscopy have been used successfully to investigate $\mathrm{P}$ species in mineral soils and other environmental samples [15]. However, none of these analytical techniques can decipher P species independently because of the complex chemical and biochemical processes of $\mathrm{P}$ such as dissolution-precipitation, sorption-desorption, mineralization-immobilization, and oxidation-reduction [16]. Thus, the combined use of wet chemical and spectroscopic analytical techniques could provide detailed information on the impacts of management practices on various $\mathrm{P}$ species distributions and transformations.

About 30,000 ha of degraded peatlands have been rewetted in Mecklenburg-West Pomerania, northern German since the mid-1990s [17,18]. Most of the rewetted peatlands were put under nature conservation, while the usual drainage has been continued to enable grazing, haymaking, and afforestation. Only a few studies investigated different $P$ fractions in recently rewetted percolation mires $[13,19,20]$. Understanding the influence of such long-term drainage and rewetting of different peatland types on $\mathrm{P}$ biogeochemistry can provide an opportunity to improve future practice for sustainable use of a peatland ecosystem. Thus, the objectives of this study were to (i) speciate $P$ in surface and subsurface horizons of long-term drained and rewetted percolation mires, forest, and coastal peatlands with the combined use of wet chemical and advanced spectroscopic analyses (ii) examine the influence of drainage and rewetting on P-distributions and transformations.

\section{Materials and Methods}

\subsection{Site Description and Soil Sampling}

Soil samples were collected from pairs of three different peatland types including the drained and rewetted sites of forest, coastal, and percolation mires in Mecklenburg-West Pomerania, northern Germany. Although there was no historical record of the initial drainage date, most intensive drainages occurred in 1960 to 70ies. The present study sites have rewetted since the mid-1990s. The latitude and longitude of the sampling points, depth of water table, peat accumulation depths, altitudes, and dominant plant species, mean annual temperature and rainfall of the study sites have already published [21]. The soil samples were collected from 0 to $80 \mathrm{~cm}$ soil depth and the sampling depths depending on the thickness of the accumulated peats, which ranged from $0.3 \mathrm{~m}$ to $>1.0 \mathrm{~m}$. We collected 72 soil samples from six sites; three drained and three rewetted peatlands at the beginning of June 2017. We transported the collected soil samples to the laboratory in a cooling box and then placed in a freezer at $-20^{\circ} \mathrm{C}$ immediately. The types of horizons, sampling depths, degree of humification, water content at sampling, and soil $\mathrm{pH}$ have also published elsewhere [21]. The soils of the study sites were characterized following the procedures of FAO [22]. The major soil units were Folic Histosol for the drained forest peatland, drained percolation mire, drained and rewetted coastal peatlands and Sapric Histosol for the rewetted forest peatland and percolation mire according to the International Union of Soil Science Working Group World Reference for Soil Resources [23]. The subsample of the frozen soil samples was freeze-dried and used for wet-chemical, ${ }^{31} \mathrm{P}$ NMR, 
and XANES analyses. The concentration of all elements and $P$ fractions were reported per oven-dried weight basis of the soil samples.

\subsection{Total Elements and Plant Available P Analyses}

The freeze-dried soil samples were ground by a ball mill to $<0.5 \mathrm{~mm}$ sieve size and used for the determination of total elements. The concentrations of total $\mathrm{P}, \mathrm{K}, \mathrm{Ca}, \mathrm{Mg}, \mathrm{Al}, \mathrm{Fe}, \mathrm{Mn}$, and $\mathrm{Na}$ were extracted by microwave-assisted aqua regia digestion of the soil samples and their concentrations were determined by inductively coupled plasma-optical emission spectroscopy (ICP-OES) (PerkinElmer Optima 8300, Waltham, MA, USA). In addition to microwave-assisted aqua regia digestion, we used the ignition method for the determination of total $P_{o}$ [24]. Briefly, $1.00 \mathrm{~g}$ of soil samples $(<2 \mathrm{~mm})$ of the surface horizon and deepest subsurface horizons were weighed into the porcelain crucibles, and the crucibles were placed in the cool muffle furnace which was heated gradually to $550{ }^{\circ} \mathrm{C}$ and maintained for three hours at this temperature. The ignited samples were transferred to $50 \mathrm{~mL}$ centrifuge tubes. Similarly, we weighed $1.00 \mathrm{~g}$ of unignited soil samples in a $50 \mathrm{~mL}$ centrifuge tube. We added $25 \mathrm{~mL}$ of $0.5 \mathrm{M} \mathrm{H}_{2} \mathrm{SO}_{4}$ to both ignited and unignited samples, and the samples were shaken for $16 \mathrm{~h}$, centrifuged for $30 \mathrm{~min}$ at $4500 \mathrm{~g}$ and filtered. The P concentration in the aliquot was determined by ICP-OES. The P concentration in the unignited samples was assumed to be $P_{i}$ and the difference between the total $P$ concentrations of the ignited and unignited peat soil samples were reported as total $P_{0}$.

The plant available $\mathrm{P}$ was extracted by double lactate (DL) following the procedures outlined in the LUFA Method Book [25]. The field moist soil samples, equivalent to $0.60 \mathrm{~g}$ oven dried sample was weighed into $50 \mathrm{~mL}$ centrifuge tube and $30 \mathrm{~mL}$ DL working solution was added. The samples were shaken for $30 \mathrm{~min}$ using the overhead shaker, centrifuged for $15 \mathrm{~min}$ and the filtered solution was used for determination of the plant available P concentration by ICP-OES.

\subsection{Sequential P Fractionation}

About $0.50 \mathrm{~g}$ of peat soil sample was weighed into the $50 \mathrm{~mL}$ centrifuge tube. The anion exchange membrane (AEM), $0.5 \mathrm{M} \mathrm{NaHCO}_{3}$ at $\mathrm{pH} 8.5,0.1 \mathrm{M} \mathrm{NaOH}$, and $1.0 \mathrm{M} \mathrm{H}_{2} \mathrm{SO}_{4}$ were used to sequentially extract different $P$ fractions $[15,26]$. Each fractionation step was performed in a 1:60 weight to volume ratio in triplicate. The samples were shaken at $60 \mathrm{rpm}$ using a reciprocal shaker for $16 \mathrm{~h}$ and then centrifuged at $4500 \mathrm{~g}$ for $30 \mathrm{~min}$. The $\mathrm{P}_{\mathrm{i}}$ concentration in all extracts was determined by the molybdenum blue method [27] using a SPECORD 50 PLUS ultraviolet/visible (UV/Vis) spectrophotometer (Analytik Jena AG, Jena, Germany), whereas the concentration of total $P$ in each $P$ fraction determined by ICP-OES. The concentration of $P_{o}$ was obtained by the difference of the concentration of total $P$ and $\mathrm{P}_{\mathrm{i}}$ of each fraction, whereas the residual $\mathrm{P}$ was the difference of total $\mathrm{P}$ and the sum of all $\mathrm{P}_{\mathrm{i}}$ and $\mathrm{P}_{\mathrm{o}}$ fractions. The AEM-P, $\mathrm{NaHCO}_{3}-\mathrm{P}$ are assumed labile $\mathrm{P}, \mathrm{NaOH}-\mathrm{P}$ is moderately labile, and $\mathrm{H}_{2} \mathrm{SO}_{4}-\mathrm{P}$ and Residual-P are stable $\mathrm{P}$ pools of $\mathrm{P}_{\mathrm{i}}$ and $\mathrm{P}_{\mathrm{o}}$ [28].

\subsection{Solution ${ }^{31}$ P Nuclear Magnetic Resonance (NMR) and P K X-ray Absorption Near Edge Structure (XANES) Analyses}

For ${ }^{31} \mathrm{P}$ NMR analysis, the $\mathrm{P}$ was extracted by a single step extraction with $0.25 \mathrm{M} \mathrm{NaOH}-0.05 \mathrm{M}$ Ethylenediaminetetraacetic acid disodium salt dehydrate ( $\mathrm{Na}_{2}$ EDTA) ( $\left.\mathrm{NaOH}-\mathrm{EDTA}\right)$ from the soil samples of the surface and deepest horizons following the procedures outlined by Cade-Menun [29]. The extraction was done at 1:20 soil to solution ratio, by shaking for $16 \mathrm{hr}$, followed by centrifugation at $4500 \mathrm{~g}$ for $30 \mathrm{~min}$, and filtration. The filtered samples were frozen immediately at $-20{ }^{\circ} \mathrm{C}$, and then freeze-dried. Before ${ }^{31} \mathrm{P}$ analysis, we dissolved 100 to $200 \mathrm{mg}$ freeze-dried samples in 600 to $1000 \mu \mathrm{L}$ of $30 \% \mathrm{NaOD}$ and $\mathrm{D}_{2} \mathrm{O}$ mixture. We added 200 to $500 \mathrm{mg}$ of $\mathrm{Na}_{2} \mathrm{~S} \cdot 9 \mathrm{H}_{2} \mathrm{O}$ depending on the Fe content of the samples as recommended by Vestergren et al. [30]. The samples were vortexed for $2 \mathrm{~min}$ for the complete dissolution of $\mathrm{Na}_{2} \mathrm{~S} \cdot 9 \mathrm{H}_{2} \mathrm{O}$ and centrifuged at $45,000 \mathrm{~g}$ for $15 \mathrm{~min}$, and the clear solution was used for the ${ }^{31} \mathrm{P}$ NMR analysis. 
The solution ${ }^{31} \mathrm{P}$ NMR spectra were recorded using an inverse gated decoupled (IG) pulse sequence on a Bruker Avance 500 spectrometer with a pulse width of $30^{\circ}(3.3 \mu \mathrm{s}), 1.64 \mathrm{~s}$ acquisition time, $5.0 \mathrm{~s}$ pulse delay, 10,000 scans and a temperature of $298 \mathrm{~K}$. The chemical shifts of signals were determined in parts per million ( $\mathrm{ppm}$ ) relative to the reference $\mathrm{P}$ compounds used along with the samples. In this study, we used inositol hexakisphosphate (IHP), glucose 6-P, glucose-1-P, adenosine $5^{\prime}$ monophosphate (AMP), deoxyribonucleic acid (DNA), and $\alpha$ - and $\beta$-glycerophosphates for the reference $P$ compounds for peak identification as recommended by Cade-Menun [29]. The NMR spectra were processed by Topspin 3.6.1 version. Here we reported the NMR data of surface horizons because we did not get reliable NMR data from the subsurface horizons because of high viscosity due to high organic matter concentrations along with low $\mathrm{P}$ and high Fe contents of the samples.

For P K-edge XANES analysis, we followed the detailed procedures described by Prietzel et al. [31]. The spectra were acquired at beamline 8 of the electron storage ring $(1.2 \mathrm{GeV}$; bending magnet; beam current 69-149 mA; 1.1 to 1.71011 photons s$^{-1}$ ) at the Synchrotron Light Research Institute (SLRI) in Nakhon Ratchasima, Thailand. Finely ground homogenized powder of each sample was spread as a thin film $(2 \mathrm{~cm} \times 0.5 \mathrm{~cm})$ and carefully distributed with a spatula to yield a homogeneous particle distribution on Kapton tape (Lanmar Inc., Northbrook, IL, USA) and then mounted on a sample holder. After energy calibration using elemental $\mathrm{P}$ powder $(\mathrm{E}=2145.5 \mathrm{eV}$; precision $0.11 \mathrm{eV})$, spectra were acquired in the energy range of $2110-2350 \mathrm{eV}$ in $5.0 \mathrm{eV}$ increment ( 2105 to $2135 \mathrm{eV} ; 2205$ to $2350 \mathrm{eV}$ ) and $0.25 \mathrm{eV}$ increment (2135 to $2205 \mathrm{eV}$ ). Spectrum acquisition time was $3 \mathrm{sec}$, and incident $\mathrm{X}$-ray intensity was measured using a $\mathrm{N}_{2}$ gas-filled ion chamber while the fluorescence emitted from the sample was recorded with a 13-channel Ge detector. For each sample, three spectra were acquired and merged, and the spectra were baseline corrected; pre-edge (energy: 2115-2145 eV) and post edge (energy region: 2190-2215 eV) using the software package ATHENA [32]. We also used the ATHENA software package for the linear combination fitting (LCF) to relatively quantify $P$ species. We used spectra of the following reference compounds for LCF: amorphous $\mathrm{AlPO}_{4}$, Ca-phytate, crystalline $\mathrm{AlPO}_{4}, \mathrm{FePO}_{4}$, Ca-hydroxyapatite, IHP, ferrihyderite-IHP, montmorillonite-Al-IHP, ferrihydrite- $\mathrm{PO}_{4}$, soil organic matter (SOM)-Al-IHP, montmorillonite-Al- $\mathrm{PO}_{4}, \mathrm{SOM}-\mathrm{Al}-\mathrm{PO}_{4}$, boehmite- $\mathrm{PO}_{4}, \mathrm{CAHPO}_{4}, \mathrm{CaH}_{2} \mathrm{PO}_{4}$, crysralline- $-\mathrm{FePO}_{4}$, and $\mathrm{MgHPO}_{4}$ [31].

\subsection{Statistical Analysis}

The analysis of variance of the total concentration of the selected elements and different $P$ fractions was conducted by the SAS software [33] using PROC GLIMMIX. The different soil depths in different peatland types were treated as the fixed effect, whereas the replication and replication $\mathrm{x}$ soil depth interaction were treated as the random effect. The normality was tested before running any statistical analysis, and all the selected total elements and $\mathrm{P}$ fractions were normally distributed, and thus we ran the statistical analysis using the original data without data transformation.

\section{Results}

\subsection{Total Elements and Plant-Available P}

The total concentrations of elements that potentially form bindings with $\mathrm{P}$ compounds were significantly $(p<0.05)$ different among the soil horizons of the studied peatlands (Table S1). Total Ca was the most abundant among the elements in the rewetted forest peatland, drained and rewetted percolation mires but it was significantly lower at the surface horizons of the drained forest peatlands, drained, and rewetted coastal peatlands. However, the concentrations of total $\mathrm{P}$ and $\mathrm{K}$ were significantly higher in the surface than the subsurface horizons and decreased with depths (Table S1). The concentrations of total $\mathrm{Mg}$ in the coastal peatlands were significantly $(p<0.05)$ higher than in the other peatlands. The concentration of total Fe was significantly higher in the rewetted forest peatland than in the other studied peatlands. The concentration of Al was significantly higher in the coastal peatlands and drained 
forest peatlands than in the other peatlands. As compared to the other elements, the concentrations of $\mathrm{K}, \mathrm{Na}$, and $\mathrm{Mn}$ were lower in all horizons and different peatland types.

The concentration of plant available P differed significantly between the surface and subsurface horizons except for the rewetted percolation mire (Figure 1). Similar to the total P (Table S1), the plant available P significantly decreased from the surface to the subsurface horizons. The concentration of plant available $\mathrm{P}$ was also significantly higher at the surface than at the subsurface horizons while there were no significant differences $(p>0.05)$ among the subsurface horizons except at the rewetted percolation mire.

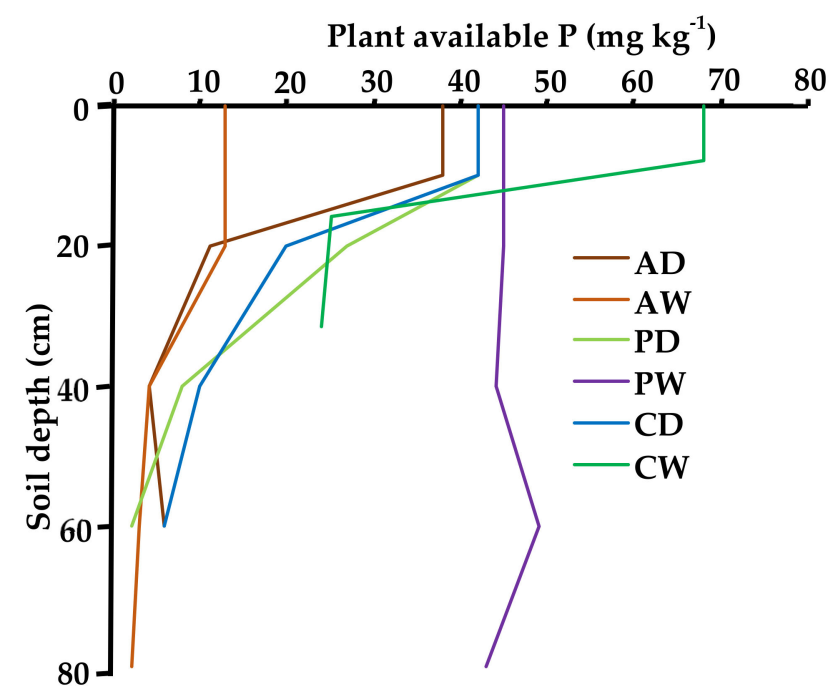

Figure 1. Content of plant available $P$ in the different management and peatland types extracted by double lactate. Standard error of the mean: $12 \mathrm{mg} \mathrm{P} \mathrm{kg}^{-1}$. AD: drained forest peatland, AW: rewetted forest peatland, PD: drained percolation mire, PW: rewetted percolation mire, CD: drained coastal influenced peatland, CW: rewetted coastal influenced peatland.

\subsection{Phosphorus Fractions Recovered by Different Methods}

The concentrations of $P_{i}$ fractions recovered by sequential $P$ fractionation were lower than the concentrations of their respective $P_{o}$ and residual-P (Table 1). The concentrations of soluble $P_{i}$ extracted by anion exchange membrane $\left(\mathrm{AEM}-\mathrm{P}_{\mathrm{i}}\right)$, labile $\mathrm{P}_{\mathrm{i}}\left(\mathrm{NaHCO}_{3}-\mathrm{P}_{\mathrm{i}}\right)$, and moderately labile $\mathrm{P}_{\mathrm{i}}\left(\mathrm{NaOH}-\mathrm{P}_{\mathrm{i}}\right)$ were mostly significantly $(p<0.05)$ different among the surface and subsurface horizons. These three $P_{i}$ fractions also decreased from the surface to the subsurface horizons. In contrast to the AEM- $P_{i}$, $\mathrm{NaHCO}_{3}-\mathrm{P}_{\mathrm{i}}$, and $\mathrm{NaOH}-\mathrm{P}_{\mathrm{i}}$ fractions, the distribution of stable $\mathrm{P}_{\mathrm{i}}\left(\mathrm{H}_{2} \mathrm{SO}_{4}-\mathrm{P}_{\mathrm{i}}\right)$ fraction from the surface to subsurface horizons was different for the different peatland types. The $\mathrm{H}_{2} \mathrm{SO}_{4}-\mathrm{P}_{\mathrm{i}}$ fraction increased from the surface to subsurface horizons in the drained forest and coastal peatlands, whereas it decreased from the surface to subsurface horizons in the rewetted forest, rewetted coastal peatland, and percolation mires.

Similar to $\mathrm{NaHCO}_{3}-\mathrm{P}_{\mathrm{i}}$ and $\mathrm{NaOH}-\mathrm{P}_{\mathrm{i}}$ fractions, their respective labile $\mathrm{P}_{\mathrm{o}}\left(\mathrm{NaHCO}_{3}-\mathrm{P}_{\mathrm{o}}\right)$ and moderately labile $\mathrm{P}_{\mathrm{o}}\left(\mathrm{NaOH}-\mathrm{P}_{\mathrm{o}}\right)$ fractions decreased from the surface to the subsurface horizons (Table 1). However, the $\mathrm{NaHCO}_{3}-\mathrm{P}_{\mathrm{o}}$ was less than the $\mathrm{NaOH}-\mathrm{P}_{\mathrm{o}}$ at both the surface and subsurface horizons. The concentration of the residual-P, the second to the NaOH-P fraction, significantly decreased from the surface to the subsurface horizons. Furthermore, the residual-P was lower in the drained than in its respective rewetted peatland except for the percolation mires (Table 1). The proportion of $\mathrm{H}_{2} \mathrm{SO}_{4}-\mathrm{P}$ and residual-P was $57 \%$ in the surface horizons of the rewetted forest peatland, whereas these fractions accounted for only $32 \%$ in the drained forest peatland (Figure 2a). Similarly, the relative contribution of the $\mathrm{H}_{2} \mathrm{SO}_{4}-\mathrm{P}$ and residual-P to the total $\mathrm{P}$ of the rewetted and drained coastal peatlands were $48 \%$ and $40 \%$ (Figure $2 \mathrm{~b}$ ), and that of the rewetted and drained percolation mires were $67 \%$ and $59 \%$, respectively (Figure $2 \mathrm{c}$ ). 
Table 1. Contents of phosphorus fractions extracted by sequential fractionation method.

\begin{tabular}{|c|c|c|c|c|c|c|c|c|c|}
\hline \multirow[b]{2}{*}{ Site } & \multirow{2}{*}{$\frac{(\mathrm{cm})}{\text { Depth }}$} & \multicolumn{8}{|c|}{ (mg P kg ${ }^{-1}$ Oven Dried Sample) } \\
\hline & & AEM-P $_{i}$ & $\mathrm{NaHCO}_{3}-\mathrm{P}_{\mathbf{i}}$ & $\mathrm{NaOH}-\mathrm{P}_{\mathbf{i}}$ & $\mathrm{H}_{2} \mathrm{SO}_{4}-\mathrm{P}_{\mathrm{i}}$ & $\mathrm{NaHCO}_{3}-\mathrm{P}_{\mathbf{o}}$ & $\mathrm{NaOH}-\mathrm{P}_{\mathrm{o}}$ & $\mathrm{H}_{2} \mathrm{SO}_{4}-\mathrm{P}_{\mathrm{o}}$ & Residual-P \\
\hline \multirow{4}{*}{$\mathrm{AD}$} & $0-10$ & $37^{\mathrm{cd}}$ & $14^{\text {ef }}$ & $14^{\text {cdefh }}$ & $15^{\mathrm{j}}$ & $213^{b}$ & $399^{c}$ & 52 efgh & $278^{\text {fgh }}$ \\
\hline & $10-20$ & 21 hijk & $11^{\text {ef }}$ & $16^{\text {cdef }}$ & $13^{j}$ & 137 ef & $305^{\text {de }}$ & $57^{\text {defg }}$ & $114^{\mathrm{ijk}}$ \\
\hline & $20-40$ & 24 fghijk & 12 ef & 12 efhi & 19 ij & $143^{\text {ed }}$ & $307^{\text {de }}$ & $71^{\mathrm{d}}$ & 172 hij \\
\hline & $40-60$ & 22 ghijk & $7^{\mathrm{f}}$ & $8^{\mathrm{jk}}$ & $56^{\mathrm{fg}}$ & $47^{\mathrm{ij}}$ & $95^{1 \mathrm{~km}}$ & 47 fghi & $132 \mathrm{ijk}$ \\
\hline \multirow{4}{*}{ AW } & $0-20$ & $38^{\mathrm{bc}}$ & $39^{b}$ & $76^{a}$ & $319^{a}$ & $200^{b c}$ & $530^{\mathrm{b}}$ & $121^{\mathrm{b}}$ & $749^{b}$ \\
\hline & $20-40$ & $28^{\text {defgh }}$ & $10^{\text {ef }}$ & $11^{\mathrm{fhi}}$ & $76^{e}$ & $111^{\mathrm{fg}}$ & $295^{\text {def }}$ & $74^{\mathrm{cd}}$ & $347^{\text {ef }}$ \\
\hline & $40-60$ & $35^{\text {cde }}$ & $8^{\mathrm{f}}$ & 10 hij & $51^{\mathrm{gh}}$ & $84^{\mathrm{gh}}$ & 193 hij & 62 def & $270^{\text {fgh }}$ \\
\hline & $60-80$ & 23 ghijk & $7^{\mathrm{f}}$ & $10^{\text {hij }}$ & $24^{\mathrm{ij}}$ & $56^{\mathrm{hi}}$ & $126^{\mathrm{jkl}}$ & $37^{\mathrm{ijk}}$ & 169 hij \\
\hline \multirow{5}{*}{$\mathrm{CD}$} & $0-10$ & $33^{\text {cdef }}$ & $34^{b c}$ & 11 hij & $46^{\mathrm{gh}}$ & $289^{a}$ & $326^{\mathrm{d}}$ & $43^{\text {hij }}$ & 383 def \\
\hline & $10-20$ & 27 efghi & $26^{\mathrm{cd}}$ & $11^{\mathrm{hij}}$ & $51 \mathrm{gh}$ & $213^{b}$ & $248^{\text {efgh }}$ & $36^{\mathrm{k}}$ & $64^{\mathrm{jk}}$ \\
\hline & $20-30$ & 19 hijk & $13^{\text {ef }}$ & $12^{\text {cdefh }}$ & 74 ef & $132 \mathrm{ef}$ & 225 ghi & 48 fghi & $106^{\mathrm{ijk}}$ \\
\hline & $30-40$ & 20 hijk & $21^{\mathrm{ed}}$ & $19^{c}$ & $77^{\mathrm{e}}$ & 150 ed & $237 \mathrm{fgh}$ & 44 ghij & $36^{\mathrm{k}}$ \\
\hline & $40-60$ & $18^{\mathrm{ijk}}$ & $14^{\text {ef }}$ & $7^{\mathrm{k}}$ & $9^{j}$ & $95 \mathrm{~g}$ & $159^{\mathrm{ijk}}$ & $17^{\mathrm{m}}$ & $275^{f g h}$ \\
\hline \multirow{3}{*}{$\mathrm{CW}$} & $0-10$ & $47^{\mathrm{ab}}$ & $50^{a}$ & $16^{\text {cdef }}$ & $75^{\mathrm{e}}$ & $212^{b}$ & $403^{c}$ & $64 \mathrm{de}$ & $581^{c}$ \\
\hline & $10-20$ & 27 efghi & $28^{\mathrm{bcd}}$ & 10 hij & $56^{\mathrm{fg}}$ & $171^{\mathrm{cd}}$ & 210 ghi & $32 \mathrm{kl}$ & 224 ghi \\
\hline & $20-30$ & $26^{\text {fghij }}$ & $28 \mathrm{bcd}$ & 12 efhi & 35 hi & $155^{\text {ed }}$ & $182^{\text {hij }}$ & $26^{1}$ & $146^{\mathrm{ijk}}$ \\
\hline \multirow{4}{*}{ PD } & $0-10$ & $55^{\mathrm{a}}$ & $35^{b c}$ & $56^{\mathrm{b}}$ & $328^{a}$ & $280^{a}$ & $617^{a}$ & $235^{a}$ & $937^{a}$ \\
\hline & $10-20$ & $31^{\text {cdefg }}$ & $26^{\mathrm{cd}}$ & $54^{\mathrm{b}}$ & $146^{\mathrm{b}}$ & $109 \mathrm{fg}$ & $268^{\text {defg }}$ & $98^{b c}$ & $168^{\mathrm{hij}}$ \\
\hline & $20-40$ & 20 hijk & $11^{\text {ef }}$ & $18^{\mathrm{dc}}$ & $14^{\mathrm{j}}$ & $31^{\mathrm{ijk}}$ & $82^{\mathrm{lm}}$ & $42^{\text {hijk }}$ & $277^{\mathrm{fgh}}$ \\
\hline & $40-60$ & $16^{\mathrm{k}}$ & $7^{\mathrm{f}}$ & $15^{\text {cdefc }}$ & $14^{\mathrm{j}}$ & $13^{j \mathrm{k}}$ & $43^{\mathrm{m}}$ & $39 \mathrm{ijk}$ & $915^{a}$ \\
\hline \multirow{5}{*}{ PW } & $0-20$ & 27 efghi & $14^{\text {ef }}$ & $13^{\text {defh }}$ & $114^{\mathrm{c}}$ & $59 \mathrm{hi}$ & $234^{\mathrm{fgh}}$ & $98^{b c}$ & $498^{\mathrm{cd}}$ \\
\hline & $20-40$ & 21 hijk & $7^{\mathrm{f}}$ & 10 hij & $102^{\mathrm{cd}}$ & $18^{\mathrm{jk}}$ & $57 \mathrm{~m}$ & $43^{\text {hijk }}$ & $348^{\text {ef }}$ \\
\hline & $40-60$ & 22 ghijk & $8^{f}$ & 10 hij & $100 \mathrm{~cd}$ & $40^{\mathrm{ij}}$ & $661^{\mathrm{m}}$ & 59 def & $414^{\text {ed }}$ \\
\hline & $60-80$ & $18^{\mathrm{jk}}$ & $6^{f}$ & 9 hijk & 83 de & $4^{\mathrm{k}}$ & $42^{\mathrm{m}}$ & 51 efgh & 337 efg \\
\hline & SE & 3 & 4 & 3 & 6.8 & 11 & 24 & 9 & 42 \\
\hline
\end{tabular}

AD: drained forest peatland, AW: rewetted forest peatland, PD: drained percolation mire, PW: rewetted percolation mire, CD: drained coastal influenced peatland, CW: rewetted coastal influenced peatland. Different letters within the column indicate significant difference at $(p<0.05)$. 

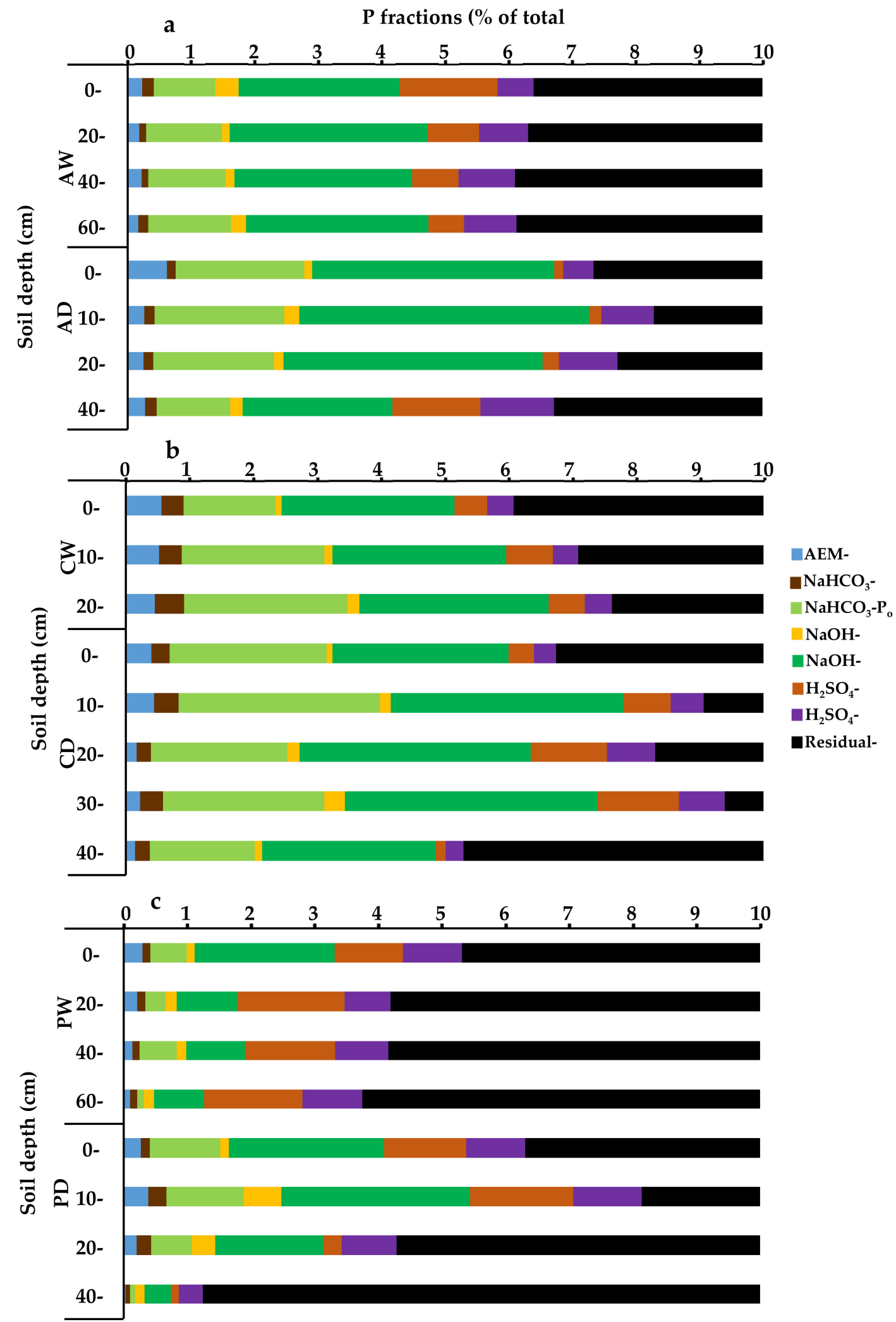

Figure 2. Relative proportions of different $\mathrm{P}$ fractions in the drained and rewetted peatlands. (a): drained and rewetted forest peatlands, (b): drained and rewetted coastal peatlands, (c): drained and rewetted peatlands. AEM-P: extracted by anion exchangeable membrane, $\mathrm{NaHCO}_{3}-\mathrm{P}_{\mathrm{i}}$ and $\mathrm{NaHCO}_{3}-\mathrm{P}_{\mathrm{o}}$ : labile inorganic and organic $\mathrm{P}, \mathrm{NaOH}-\mathrm{P}_{\mathrm{i}}$ and $\mathrm{NaOH}-\mathrm{P}_{\mathrm{o}}$ : moderately labile organic and inorganic $\mathrm{p}$, $\mathrm{H}_{2} \mathrm{SO}_{4}-\mathrm{P}$ and Residual-P: Stable inorganic and organic $\mathrm{P}$ fractions. 
The sequential $\mathrm{P}$ fractionation recovered higher proportions of total $\mathrm{P}$ from the drained than the rewetted surface horizons of the same peatland types. Accordingly, the method recovered $73 \%$ and $64 \%$ from the drained and rewetted forest peatlands, 67 and $60 \%$ from the drained and rewetted coastal peatlands, and $60 \%$ and $53 \%$ of total $P$ from the drained and rewetted percolation mires of the surface horizons, respectively (Table 1 and Figure 2).

The concentrations of total $\mathrm{P}, \mathrm{P}_{\mathrm{i}}$, and $\mathrm{P}_{\mathrm{o}}$ recovered by the ignition method were significantly $(p<0.05)$ different at the surface horizons, whereas they were not significantly different $(p>0.05)$ at the subsurface horizons (Table 2). Furthermore, the total $P$ determined by the ignition method was also similar to the total $\mathrm{P}$ determined by microwave-assisted aqua regia digestion (Table 2 and Table S1). The relative proportion of $P_{i}$ and $P_{o}$ determined by the ignition method ranged from $20 \%$ to $47 \%$ and from $53 \%$ to $80 \%$ of the total $\mathrm{P}$, respectively. The ignition method recovered the highest proportion of $P_{i}$ from the surface horizon and the highest $P_{o}$ from the subsurface horizons of the drained percolation mire. However, the lowest $P_{i}$ recovered from the surface horizon of the drained forest peatland and subsurface horizons of the rewetted forest peatlands, whereas the lowest $P_{0}$ was recovered from the surface horizon of drained percolation mire followed by surface horizons of drained coastal peatland. Similar to the sequential $\mathrm{P}$ fractionation method (Table 1), the ignition method also recovered higher concentrations of $P_{o}$ than $P_{i}$, although the absolute concentration and relative proportion of $P_{i}$ in the ignition method were higher than that was recovered by the sequential $\mathrm{P}$ fractionation.

Table 2. Phosphorus fractions determined by the ignition method.

\begin{tabular}{|c|c|c|c|c|c|c|}
\hline \multirow[b]{2}{*}{ Site } & \multirow{2}{*}{$\frac{(\mathrm{cm})}{\text { Depth }}$} & \multicolumn{3}{|c|}{ (mg P kg-1 Oven Dried Sample) } & \multicolumn{2}{|c|}{$\%$} \\
\hline & & TP & TPi & $\mathbf{T P}_{\mathbf{o}}$ & $\mathbf{T P}_{\mathbf{i}}$ & $\mathbf{T P}_{\mathbf{o}}$ \\
\hline \multirow{2}{*}{$\mathrm{AD}$} & $0-10$ & $1069 \mathrm{~cd}$ & $216^{\text {de }}$ & $852^{b c}$ & $21^{\mathrm{fg}}$ & $79^{a b}$ \\
\hline & $40-60$ & $471^{\mathrm{e}}$ & $128 \mathrm{fg}$ & $343^{\mathrm{e}}$ & $27^{\mathrm{ef}}$ & $73^{b c}$ \\
\hline \multirow{2}{*}{ AW } & $0-20$ & $1823^{b}$ & $795^{b}$ & $1027^{\mathrm{b}}$ & $43^{a b c}$ & $57^{\text {efg }}$ \\
\hline & $60-80$ & $385^{\mathrm{e}}$ & $84^{\mathrm{g}}$ & $301^{\mathrm{e}}$ & $21^{\mathrm{fg}}$ & $79^{a b}$ \\
\hline \multirow{2}{*}{$\mathrm{CD}$} & $0-10$ & $1004^{\mathrm{d}}$ & $444^{\mathrm{c}}$ & 560 de & $44^{\mathrm{ab}}$ & $56^{\mathrm{fg}}$ \\
\hline & $40-60$ & $587^{\mathrm{e}}$ & 229 de & $358^{\mathrm{e}}$ & 39 bcd & $61^{\text {def }}$ \\
\hline \multirow{2}{*}{ CW } & $0-10$ & $1291^{c}$ & $480^{c}$ & $811^{\mathrm{bcd}}$ & $37^{\mathrm{dc}}$ & $63^{\text {de }}$ \\
\hline & $20-30$ & $638^{\mathrm{e}}$ & $268^{\mathrm{d}}$ & $370^{\mathrm{e}}$ & $42^{a b c}$ & $58^{\text {efg }}$ \\
\hline \multirow{2}{*}{ PD } & $0-10$ & $2618^{a}$ & $1241^{a}$ & $1377^{\mathrm{a}}$ & $47^{\mathrm{a}}$ & $53 \mathrm{~g}$ \\
\hline & $40-60$ & $507^{\mathrm{e}}$ & $101^{\mathrm{g}}$ & $406^{\mathrm{e}}$ & $20^{g}$ & $80^{a}$ \\
\hline \multirow{3}{*}{ PW } & $0-20$ & $966^{d}$ & $273^{d}$ & $692^{\mathrm{cd}}$ & 28 ef & $72^{b c}$ \\
\hline & $60-80$ & $596^{\mathrm{e}}$ & 189 ef & $408^{\mathrm{e}}$ & 32 de & $68^{\mathrm{cd}}$ \\
\hline & SE & 88 & 24 & 88 & 3 & 3 \\
\hline
\end{tabular}

AD: drained forest peatland, AW: rewetted forest peatland, PD: drained percolation mire, PW: rewetted percolation mire, CD: drained coastal influenced peatland, CW: rewetted coastal influenced peatland. TP: total P extracted by ignition method, $\mathrm{TP}_{\mathrm{i}}$ and $\mathrm{TP}_{\mathrm{o}}$ : total inorganic $\mathrm{P}$ and organic $\mathrm{P}$ fractions, respectively. Different letters within the column indicate significant difference at $(p<0.05)$

The concentration of total $\mathrm{P}, \mathrm{P}_{\mathrm{i}}$, and $\mathrm{P}_{\mathrm{o}}$ extracted by NaOH-EDTA is presented in Table 3 . The highest concentration of total $\mathrm{P}$ was extracted from the surface horizon of the drained percolation mire followed by rewetted forest peatland. There were significant differences in total $P$ and $P_{i}$ at the surface horizons except for the coastal peatlands. However, the concentration of the total $P_{o}$ was not significantly $(>0.05)$ different at most of the surface horizons. The relative proportion of $P_{i}$ recovered by the $\mathrm{NaOH}$-EDTA was in the range of $8 \%$ to $40 \%$ of the total $\mathrm{P}$, whereas the relative proportion of $\mathrm{P}_{\mathrm{o}}$ was in the range of $17 \%$ to $67 \%$ of the total $\mathrm{P}$ determined by microwave-assisted aqua regia digestion (Table 3 and Table S3). Overall, the proportions of the total P recovered by the NaOH-EDTA were in the range of $33 \%$ to $85 \%$; the lowest proportion was recovered from the deepest horizon of drained 
percolation mire, whereas the highest proportion of the total $\mathrm{P}$ was recovered from the surface horizon of the drained forest peatland (Table 3).

Table 3. Phosphorus fractions recovered by single step $\mathrm{NaOH}-\mathrm{Na}_{2}$ EDTA (NaOH-EDTA) extraction.

\begin{tabular}{|c|c|c|c|c|c|c|c|}
\hline \multirow[b]{2}{*}{ Site } & \multirow[b]{2}{*}{$\begin{array}{c}\text { Depth } \\
\text { (cm) }\end{array}$} & \multicolumn{3}{|c|}{ (mg P kg-1 Oven Dried Sample) } & \multicolumn{3}{|c|}{$(\%)$} \\
\hline & & $\mathbf{T P}_{\mathrm{f}}$ & $\mathbf{T P}_{\mathrm{fi}}$ & $\mathbf{T P}_{\text {fo }}$ & $\mathbf{T P}_{\mathrm{fi}}$ & $\mathbf{T P}_{\text {fo }}$ & $\mathbf{T P}_{\mathrm{f}}$ \\
\hline \multirow{2}{*}{$\mathrm{AD}$} & $0-10$ & $881^{\mathrm{c}}$ & $186^{\text {ed }}$ & $696^{\mathrm{b}}$ & $18^{\mathrm{c}}$ & $67^{\mathrm{a}}$ & $85^{\mathrm{a}}$ \\
\hline & $40-60$ & $263^{\text {ef }}$ & $51 \mathrm{fg}$ & $213^{c}$ & $12^{c}$ & $51^{\mathrm{abc}}$ & $62^{\mathrm{abcd}}$ \\
\hline \multirow{2}{*}{ AW } & $0-20$ & $1500^{b}$ & $804^{a}$ & $697^{b}$ & $40^{\mathrm{a}}$ & $50 \mathrm{abc}$ & $74^{a b c}$ \\
\hline & $60-80$ & $296^{\mathrm{e}}$ & $77^{\mathrm{fg}}$ & $220^{c}$ & $18^{c}$ & $34^{\mathrm{cd}}$ & $68^{\mathrm{abcd}}$ \\
\hline \multirow{2}{*}{$\mathrm{CD}$} & $0-10$ & $907^{c}$ & $191^{\mathrm{d}}$ & $715^{b}$ & $14^{\mathrm{c}}$ & $50^{a b c}$ & $63^{\mathrm{abcd}}$ \\
\hline & $40-60$ & 271 ef & $53^{\mathrm{fg}}$ & $218^{c}$ & $12^{c}$ & $48^{\mathrm{abc}}$ & $60 \mathrm{bcd}$ \\
\hline \multirow{2}{*}{$\mathrm{CW}$} & $0-10$ & $1002^{c}$ & $324^{c}$ & $679^{b}$ & $34^{\mathrm{ab}}$ & $46^{b c}$ & $68^{\mathrm{abcd}}$ \\
\hline & $20-30$ & $321^{\mathrm{e}}$ & $188^{\mathrm{de}}$ & $133^{c}$ & $22^{b c}$ & $17^{\mathrm{d}}$ & 51 cde \\
\hline \multirow{2}{*}{ PD } & 0-10 & $1833^{a}$ & $494^{b}$ & $1340^{a}$ & $21^{b c}$ & $57^{\mathrm{ab}}$ & $79^{a b}$ \\
\hline & $40-60$ & $143^{f}$ & $41^{\mathrm{g}}$ & $103^{c}$ & $10^{c}$ & $24^{\mathrm{d}}$ & $33^{\mathrm{e}}$ \\
\hline \multirow{3}{*}{ PW } & $0-20$ & $663^{d}$ & 115 ef & $581^{b}$ & $21^{b c}$ & $54^{a b c}$ & $62 \mathrm{abcd}$ \\
\hline & $60-80$ & 254 ef & $82^{\mathrm{fg}}$ & $140^{c}$ & $8^{c}$ & $25^{\mathrm{d}}$ & $45^{\mathrm{de}}$ \\
\hline & SE & 46 & 24 & 47 & 5 & 7 & 8 \\
\hline
\end{tabular}

Full names of the sites are given in Tables 1 and 2. $\mathrm{TP}_{\mathrm{f}}$ : total $\mathrm{P}$ fractions extracted by NaOH-EDTA, TP $\mathrm{fi}_{\mathrm{fi}}$ and $\mathrm{TP}_{\mathrm{fo}}$ : total inorganic $\mathrm{P}$ and organic $\mathrm{P}$ fractions, respectively. Different letters within the column indicate significant difference at $(p<0.05)$.

The concentrations of the selected elements recovered by $\mathrm{NaOH}$-EDTA were significantly different among the surface horizons (Table 4). As compared to the total element concentrations (Table S1), the $\mathrm{NaOH}-\mathrm{EDTA}$ recovered less than $50 \%$ of the concentration of total elements except for Ca. Similarly, the method extracted the highest concentration of Fe from the rewetted forest peatland followed by the drained percolation mire.

Table 4. Selected elements recovered by a single step extraction of the $\mathrm{NaOH}-\mathrm{Na}_{2} \mathrm{EDTA}$.

\begin{tabular}{ccccccc}
\hline & $\mathbf{( c m})$ & \multicolumn{5}{c}{$\mathbf{( g ~ k g}^{-1}$ Oven Dried Sample) } \\
\hline Site & Depth & Al & Fe & Ca & Mg & Mn \\
\hline AD & $0-10$ & $2.72^{\mathrm{a}}$ & $2.87^{\mathrm{d}}$ & $6.56^{\mathrm{c}}$ & $0.25^{\mathrm{e}}$ & $0.09^{\mathrm{c}}$ \\
AW & $0-20$ & $1.49^{\mathrm{c}}$ & $26.09^{\mathrm{a}}$ & $25.40^{\mathrm{b}}$ & $0.49^{\mathrm{c}}$ & $0.14^{\mathrm{b}}$ \\
CD & $0-10$ & $2.55^{\mathrm{a}}$ & $7.42^{\mathrm{c}}$ & $5.50^{\mathrm{c}}$ & $0.78^{\mathrm{b}}$ & $0.04^{\mathrm{d}}$ \\
CW & $0-10$ & $2.23^{\mathrm{b}}$ & $2.92^{\mathrm{d}}$ & $3.71^{\mathrm{c}}$ & $2.21^{\mathrm{a}}$ & $0.01^{\mathrm{e}}$ \\
PD & $0-10$ & $0.83^{\mathrm{d}}$ & $11.34^{\mathrm{b}}$ & $25.25^{\mathrm{b}}$ & $0.41^{\mathrm{d}}$ & $0.20^{\mathrm{a}}$ \\
PW & $0-20$ & $0.79^{\mathrm{d}}$ & $1.09^{\mathrm{e}}$ & $31.16^{\mathrm{a}}$ & $0.85^{\mathrm{b}}$ & $0.14^{\mathrm{b}}$ \\
\hline & SE & 0.06 & 0.01 & 1.10 & 0.02 & 0.01 \\
\hline
\end{tabular}

AD: drained forest peatland, AW: rewetted forest peatland, PD: drained percolation mire, PW: rewetted percolation mire, CD: drained coastal influenced peatland, CW: rewetted coastal influenced peatland. Different letters within the column indicate significant differences at $(p<0.05)$.

\subsection{Solution ${ }^{31} P N M R$}

The solution ${ }^{31} \mathrm{P}$ NMR analysis revealed the presence of orthophosphate, IHP, $\alpha$-and $\beta$-glycerol phosphates, DNA, AMP, and pyrophosphate (Figure 3 and Table 5). The $\alpha$ - and $\beta$-glycerol phosphates were the predominant $\mathrm{P}$ species followed by the IHP. Except for the rewetted percolation mire, the proportion of orthophosphate detected by the solution ${ }^{31} \mathrm{P}$ NMR analysis was higher than the orthophosphate extracted by the sequential P fractionation (Table 1), ignition method (Table 2), 
and $\mathrm{NaOH}$-EDTA (Table 3). The presence of pyrophosphate in some samples slightly overestimated the absolute and relative proportion of $\mathrm{P}_{\mathrm{o}}$ by the sequential $\mathrm{P}$ fractionation and $\mathrm{NaOH}$-EDTA methods (Tables 1 and 5).
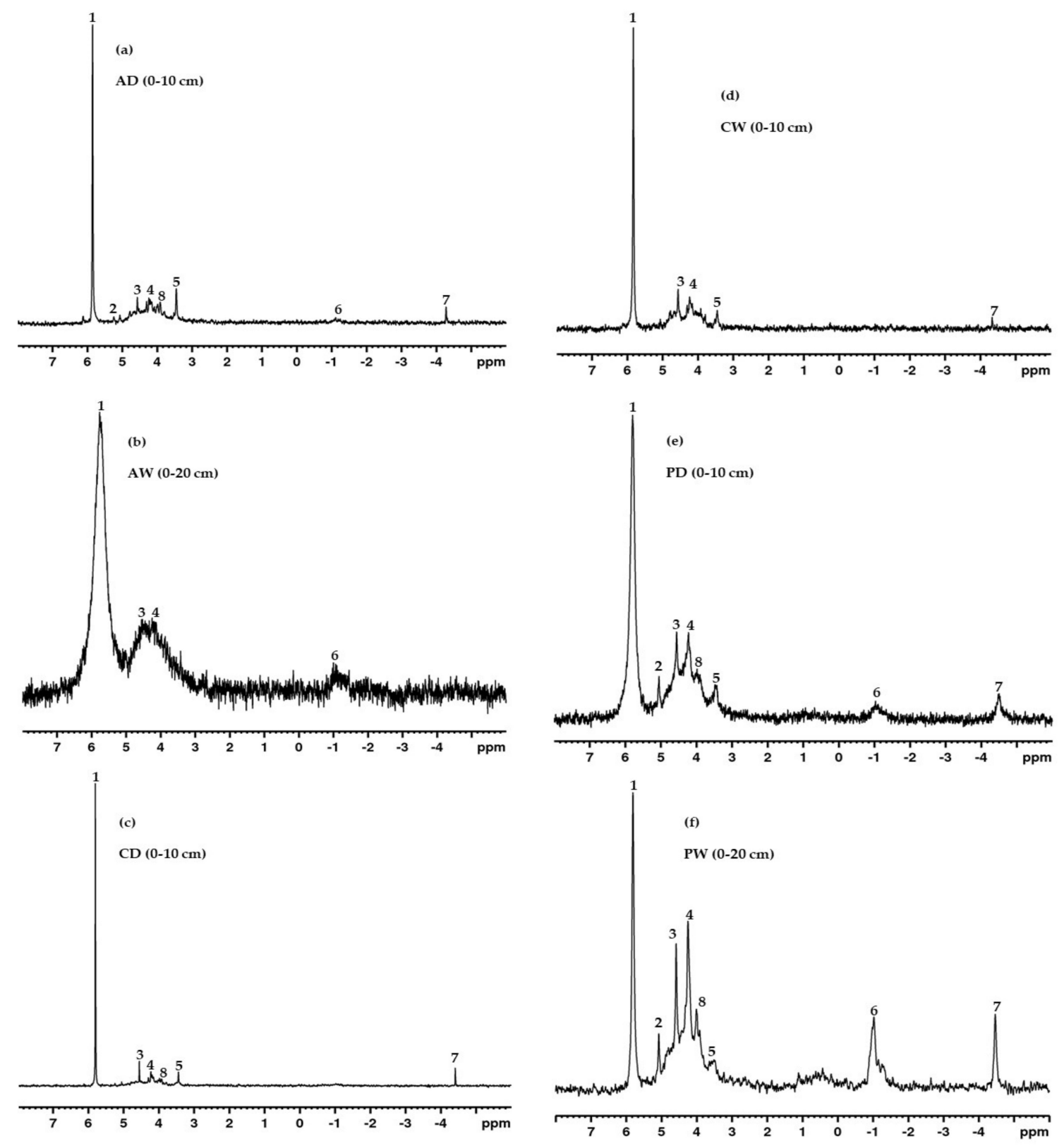

Figure 3. Solution ${ }^{31} \mathrm{P}$ nuclear magnetic resonance (NMR) spectra of the surface soil horizons of the drained and rewetted peatlands. AD: drained forest peatland, AW: rewetted forest peatland, CD: drained coastal peatland, CW: rewetted coastal peatland, PD: drained percolation mire, PW: rewetted percolation mire. 1: orthophosphate, 2: IHP, 3: $\alpha$-glycerol phosphate, 4: $\beta$-glycerol phosphate, 5: IHP, 6: DNA, 7: pyrophosphate, 8: AMP. The line broadening of (b) was due to the highest concentration Fe in the extracted soil solution (Table 4). Numbers in the parenthesis next to the abbreviation of the site names indicate soil-sampling depth. 
Table 5. Proportions of phosphorus species, $\mathrm{P}_{\mathrm{i}}$, and $\mathrm{P}_{\mathrm{o}}$ determined by the solution ${ }^{31} \mathrm{P}$ NMR analysis.

\begin{tabular}{|c|c|c|c|c|c|c|c|c|c|c|c|}
\hline \multicolumn{12}{|c|}{ Chemical Shift (ppm) } \\
\hline & & $6.0-5.78$ & $5.09-5.06$ & $4.67-4.58$ & $4.39-4.25$ & $4.20-4.11$ & $4.00-3.48$ & 0.9-1.05 & $-4.45-(-4.47)$ & & \\
\hline & $(\mathrm{cm})$ & \multicolumn{8}{|c|}{ Integrated area of the spectra (\%). } & \multicolumn{2}{|c|}{ Total P (\%) } \\
\hline Site & depth & Ortho & IHP & $\alpha$-glycerol & $\beta$-glycerol & AMP & IHP & DNA & Pyro. & $P_{i}$ & $P_{\mathrm{o}}$ \\
\hline $\mathrm{AD}$ & $0-10$ & 41 & 6 & 10 & 15 & 9 & 10 & 3 & 6 & 47 & 53 \\
\hline $\mathrm{AW}$ & $0-20$ & 66 & & & 29 & & & 5 & & 66 & 34 \\
\hline $\mathrm{CD}$ & $0-10$ & 52 & 2 & 13 & 14 & 10 & 6 & & 3 & 55 & 45 \\
\hline $\mathrm{CW}$ & $0-10$ & 53 & 1 & 19 & 18 & & 8 & & 1 & 54 & 46 \\
\hline PD & $0-10$ & 55 & 4 & 12 & 16 & & 5 & 4 & 4 & 59 & 41 \\
\hline PW & $0-20$ & 25 & 5 & 15 & 26 & & 8 & 15 & 6 & 31 & 69 \\
\hline
\end{tabular}

AD: drained forest peatland, AW: rewetted forest peatland, PD: drained percolation mire, PW: rewetted percolation mire, CD: drained coastal influenced peatland, CW: rewetted coastal influenced peatland. Ortho: orthophosphate, $\alpha$-glycerol: $\alpha$-glycerolphosphate, $\beta$-glycerol: $\beta$-glycerolphosphate, IHP: inositol hexkisphosphate, AMP: adenosine 5' monophosphate, DNA: deoxyribonucleic acid, pyro: pyrophosphate, $\mathrm{P}_{\mathrm{i}}$ : ortho + pyro, $\mathrm{P}_{\mathrm{o}}$ : IHP $+\alpha$-glycerol $+\beta$-glycerol + AMP + DNA. 


\subsection{P K-Edge XANES}

The $\mathrm{P}$ K-edge XANES analysis showed that the major proportion of $\mathrm{P}$ species were $\mathrm{P}_{\mathrm{O}}$ in the form of IHP and phytate associated with $\mathrm{Ca}, \mathrm{Al}$, and boehmite, whereas the $\mathrm{P}_{\mathrm{i}}$ associated with the $\mathrm{MgHPO}_{4}$, crystalline $\mathrm{FePO}_{4}$, and amorphous $\mathrm{AlPO}_{4}$ were detected in surface and subsurface horizons of the coastal peatlands and rewetted forest peatlands. Although the relative proportion of IHP was the second abundant of $P_{o}$ species with the NMR analysis, the XANES analysis accounted for all $P_{o}$ species to IHP. Considering only the surface horizons, the proportions of $\mathrm{P}_{\mathrm{o}}$, estimated by the XANES analysis, accounted for $86 \%$ and $81 \%$ in the drained and rewetted forest peatlands, $66 \%$ and $100 \%$ in the drained and rewetted percolation mires, $73 \%$ and $66 \%$ in the drained and rewetted coastal peatlands, respectively (Table 6).

Table 6. Phosphorus species, $\mathrm{P}_{\mathrm{i}}$, and $\mathrm{P}_{\mathrm{o}}$ determined by $\mathrm{P} K \mathrm{~K}$-ray absorption near-edge structure (XANES) analysis.

\begin{tabular}{|c|c|c|c|c|c|c|}
\hline & $(\mathrm{cm})$ & & & $\%$ & & \\
\hline Site & Depth & $\begin{array}{l}\text { Best Fitted P } \\
\text { Reference }\end{array}$ & P Species & $\mathbf{P}_{\mathbf{i}}$ & $\mathbf{P}_{\mathbf{o}}$ & R-Factor \# \\
\hline \multirow{6}{*}{$\mathrm{AD}$} & \multirow[t]{4}{*}{$0-10$} & Al-phytate & 7 & \multirow[t]{4}{*}{14} & \multirow[t]{4}{*}{85} & \multirow[t]{4}{*}{0.0017} \\
\hline & & $\mathrm{MgHPO}_{4}$ & 14 & & & \\
\hline & & IHP & 37 & & & \\
\hline & & Ca-phytate & 41 & & & \\
\hline & \multirow[t]{2}{*}{$40-60$} & Ca-phytate & 3 & \multirow[t]{2}{*}{0} & \multirow[t]{2}{*}{100} & \multirow[t]{2}{*}{0.0679} \\
\hline & & Boehmite_IHP & 97 & & & \\
\hline \multirow{6}{*}{$\mathrm{AW}$} & \multirow[t]{4}{*}{$0-20$} & Boehmite_IHP & 13 & \multirow[t]{4}{*}{19} & \multirow[t]{4}{*}{82} & \multirow[t]{4}{*}{0.0017} \\
\hline & & $\mathrm{MgHPO}_{4}$ & 19 & & & \\
\hline & & Ca-phytate & 25 & & & \\
\hline & & IHP & 44 & & & \\
\hline & \multirow[t]{2}{*}{$60-80$} & Boehmite_IHP & 22 & \multirow[t]{2}{*}{0} & \multirow[t]{2}{*}{100} & \multirow[t]{2}{*}{0.0093} \\
\hline & & Ca-phytate & 78 & & & \\
\hline \multirow{7}{*}{$\mathrm{CD}$} & \multirow[t]{3}{*}{$0-10$} & Amorphous $\mathrm{AlPO}_{4}$ & 12 & \multirow[t]{4}{*}{25} & \multirow[t]{4}{*}{73} & \multirow[t]{4}{*}{0.0043} \\
\hline & & $\mathrm{MgHPO}_{4}$ & 15 & & & \\
\hline & & IHP & 28 & & & \\
\hline & & Ca-phytate & 45 & & & \\
\hline & \multirow[t]{3}{*}{$40-60$} & Amorphous $\mathrm{AlPO}_{4}$ & 10 & \multirow[t]{3}{*}{10} & \multirow[t]{3}{*}{90} & 0.0033 \\
\hline & & Ca-phytate & 40 & & & \\
\hline & & Boehmite_IHP & 50 & & & \\
\hline & $0-10$ & $\mathrm{MgHPO}_{4}$ & 17 & 34 & 66 & 0.0045 \\
\hline & & Crystalline FePO4. & 17 & & & \\
\hline & & Ca-phytate & 66 & & & \\
\hline $\mathrm{CW}$ & $20-30$ & Crystalline-AlPO4 & 12 & 44 & 56 & 0.0512 \\
\hline & & Ca-phytate & 15 & & & \\
\hline & & MgHPO4 & 32 & & & \\
\hline & & IHP & 41 & & & \\
\hline & $0-10$ & Crytalline-FePO 4 & 11 & 34 & 66 & 0.0031 \\
\hline & & $\mathrm{MgHPO}_{4}$ & 23 & & & \\
\hline PD & & Ca-phytate & 66 & & & \\
\hline & $40-60$ & Boehmite_IHP & 28 & 0 & 100 & 0.0053 \\
\hline & & Ca-phytate & 72 & & & \\
\hline & $0-20$ & IHP & 5 & 0 & 100 & 0.0037 \\
\hline & & Ca-phytate & 95 & & & \\
\hline & $60-80$ & $\mathrm{AlPO}_{4}$-Crytalline & 10 & 67 & 32 & 0.0065 \\
\hline$P W$ & & $\mathrm{Ca}\left(\mathrm{H}_{2} \mathrm{PO}_{4}\right)_{2}$ & 17 & & & \\
\hline & & Ca-phytate & 32 & & & \\
\hline & & $\mathrm{MgHPO}_{4}$ & 40 & & & \\
\hline
\end{tabular}

AD: drained forest peatland, AW: rewetted forest peatland, CD: drained coastal peatland, CW: rewetted coastal peatland, PD: drained percolation mire, PW: rewetted percolation mire. $\mathrm{P}_{\mathrm{i}}$ and $\mathrm{P}_{\mathrm{O}}$ : the proportions of inorganic and organic P estimated by the linear combination fittings. \# The R-factor is a measure of the agreement between the combined spectra of P reference compounds and the spectra of the "unknown" soil sample. The combination of compounds yielding the smallest $\mathrm{R}$-factor was chosen as the most likely representation of $\mathrm{P}$ species in the soil samples [34]. 


\section{Discussions}

\subsection{Total Elements and Plant Available Phosphorus}

The abundance of $\mathrm{Ca}, \mathrm{Mg}, \mathrm{Fe}$, and $\mathrm{Al}$ (Table S1) indicated that the studied peatlands are minerogenic [35]. The significant differences of these element concentrations among soil horizons and the peatland types can be associated with differences in pedogenesis and degree of peat degradation. As a result, peat degradation and leaching could be attributed to the low concentration of total $\mathrm{Ca}$ in relatively low soil organic matter content of the coastal peatlands [36]. However, the higher P and $\mathrm{K}$ (Table S1) concentrations at the surface than at the subsurface horizons can be explained by historical fertilizer applications. A mixture of sand and peat layers between the peat horizons explained the slight increase of the concentration of total $\mathrm{P}$ at the $20-40 \mathrm{~cm}$ soil depth of the drained forest peat (Table S1). However, the sudden increase in the concentration of total $\mathrm{P}$ at the $40-60 \mathrm{~cm}$ soil depth of the drained percolation mire could be due to $\mathrm{P}$ translocation from the P-rich surface horizon. Overall, the total $\mathrm{P}$ content of the surface and subsurface horizons was similar to those reported from fen peatlands of Aschersleben, Saxony-Anhalt and the Trebel valley, Mecklenburg-West Pomerania $[19,20]$. The lower concentrations of $\mathrm{K}, \mathrm{Na}$, and $\mathrm{Mn}$ than the other elements are explained by their lower concentrations in plant biomass and losses during the partial decomposition of the peat-forming plant materials since these ions of these elements are less strongly bound than ions of the other elements. The high concentrations of $\mathrm{Fe}$ and $\mathrm{Al}$ in the peatlands can support the formation of metal bridges between humic substances and $\mathrm{P}_{\mathrm{i}}$ complexes $[37,38]$. The high abundance of $\mathrm{Al}$ could be beneficial since Al-containing compounds were applied to increase P sorption in peat soils [39]. However, the high abundance of Fe could form redox-sensitive $\mathrm{P}$ compounds that can be mobilized in the rewetted peatland [15].

The values of the plant available $P$ of the present study (Figure 1) were higher than those reported from the different European peatlands extracted by the same method [19]. Similar to the total P (Table 2 and Table S1), the plant available P decreased from the surface to subsurface horizons. This is explained by $\mathrm{P}$ release from peat decomposition, historical fertilization, excrement from grazing animals, and external inputs with water and atmospheric deposition. The lower concentration of plant available $P$ at the subsurface than surface horizons and lack of significant differences at the subsurface horizons indicated that $\mathrm{P}$ translocation from the surface to the subsurface horizons was negligible or the leached P lost from the soil profiles. Other researchers reported the danger of $\mathrm{P}$ leaching from the surface to subsurface horizons of peat soils upon rewetting $[14,40]$. The disagreeing results can be attributed to variations in current land use, soil organic matter content, and predominant $\mathrm{P}$ species or experimental approaches, and peatland types. Overall, the plant available $P$ extracted by double lactate in the present study was lower than those extracted by ammonium lactate and sodium bicarbonate since double lactate cannot extract $\mathrm{P}$ bound to organic matter.

\subsection{Phosphorus Fractions}

The predominance of $\mathrm{P}_{\mathrm{o}}$ and residual $\mathrm{P}$ fractions with the sequential $\mathrm{P}$ fractionation method (Table 1 and Figure 2) agreed with the results of similar studies reported from peat soils of different European countries $[19,20]$. The lower concentration of $P_{i}$ than $P_{o}$ in the present study was not surprising since the soil organic matter contents of the studied peatlands were in the range of $42 \%$ to $75 \%$ at the surface horizons [21]. The distribution of the $\mathrm{H}_{2} \mathrm{SO}_{4}-\mathrm{P}_{\mathrm{i}}$ fraction in the peat horizons followed the distribution of mineral contents in the peat profiles [21], which means the higher mineral content was associated with higher concentrations of $\mathrm{H}_{2} \mathrm{SO}_{4}-\mathrm{P}_{\mathrm{i}}$.

The concentration of NaOH-P $\mathrm{P}_{\mathrm{o}}$ was larger by factor two to that of the concentration of $\mathrm{NaHCO}_{3}-\mathrm{P}_{\mathrm{o}}$ at their respective horizon indicating that the major proportion of $\mathrm{P}_{\mathrm{o}}$ existed in the moderately labile $\mathrm{NaOH}-\mathrm{P}_{\mathrm{o}}$ form. Rewetting peatlands with such a high $\mathrm{P}_{\mathrm{o}}$ content is unlikely to enhance $\mathrm{P}$ mobilization unless the $P_{\mathrm{i}}$ is associated with the redox-sensitive elements [41]. However, the XANES analysis indicated the presence of crystalline $\mathrm{FePO}_{4}$, amorphous $\mathrm{AlPO}_{4}$, and $\mathrm{MgHPO}_{4}$ only in a few horizons in the present study (Table 6). The higher proportions of $\mathrm{P}$ recovered by the sequential $\mathrm{P}$ fractionation 
from the drained than from the rewetted peatlands (Figure 2) indicated that the $\mathrm{P}$ stability was higher in the rewetted peatlands. Similarly, the lower concentration of stable $\mathrm{P}$ fractions $\left(\mathrm{H}_{2} \mathrm{SO}_{4}-\mathrm{P}+\right.$ residual-P) at the surface horizons of the drained than their respective rewetted peatlands indicated that rewetting of former drained sites could transform moderately labile P into stable P fractions.

Similar to the sequential $P$ fractionation method, the higher concentration of $P_{o}$ than $P_{i}$ with the ignition (Table 2) and NaOH-EDTA (Table 3) methods further confirmed that $\mathrm{P}_{\mathrm{o}}$ was the predominant $\mathrm{P}$ fractions in all the studied peatland types. However, the higher $P_{i}$ in the ignition method (Table 2) than in the sequential $\mathrm{P}$ fractionation (Table 1 ) and $\mathrm{NaOH}$-EDTA (Table 3) can be attributed to differences in P recovering capacity of the different methods. The sequential P fractionation recovered $54 \%$ to $94 \%$ of total $\mathrm{P}$ while the $\mathrm{NaOH}-\mathrm{EDTA}$ recovered $51 \%$ to $85 \%$ of total $\mathrm{P}$ except the subsurface horizons of percolation mires. The ignition method was assumed to recover $100 \%$ of the $P_{i}$ and $P_{o}$, although some $P_{o}$ compounds can be transformed to $P_{i}$ by this method [24]. The percent of total $P$ recovered by the $\mathrm{NaOH}$-EDTA was in the range of the results reported from diverse temperate and tropical peatlands [42]. Similar to the sequential $\mathrm{P}$ fractionation method, the NaOH-EDTA also recovered less total $P$ from the rewetted and subsurface horizons than drained surface horizons (Tables 1 and 3) which further confirmed that rewetting increased the P stability.

Comparing the present study with nine major soil groups of 13 studies (Table S2 and Figure 4) clearly illustrated the quality of the Hedley sequential $\mathrm{P}$ fractionation in distinguishing labile to stable $P$ fractions in weakly to highly weathered soils. The distribution of different $P$ fractions in the rewetted peatlands of the present study $\left(\right.$ Histosol $^{\mathrm{w}}$ ) $($ Figure 4) related more to that of the Ferralsols indicating that $\mathrm{P}$ is more stable in the long-term rewetted peatlands than in the drained peatlands (Histosol ${ }^{\mathrm{d}}$ ) and some other major soil groups. Furthermore, the difference in the distribution of $\mathrm{P}$ fractions between the mean of three drained and three rewetted peatlands of the present study were remarkable (Figure 4). Accordingly, the proportion of labile (21\%) and moderately labile $(30 \%) \mathrm{P}$ fractions in the drained peatlands were higher than the proportions of labile (12\%) and moderately labile (22\%) P fractions of the rewetted peatlands (Figure 4). This implies the stable P fractions in the drained peatlands $(49 \%)$ were less than the stable P fractions in the rewetted peatlands $(66 \%)$. Overall, the Hedley sequential $P$ fractions not only reflect the influence of land uses and soil-management practices $[15,43]$ but also the influence of soil genesis on $\mathrm{P}$ distributions and transformations [44,45]. For instance, the predominance of $\mathrm{H}_{2} \mathrm{SO}_{4}-\mathrm{P}$ fraction in the Fluvisol (Figure 4) indicated the abundance of primary phosphates like apatite and $\mathrm{P}$ associated with $\mathrm{Ca}$ (28). Although most researchers have not determined this, the $\mathrm{H}_{2} \mathrm{SO}_{4}-\mathrm{P}$ fraction also contained $\mathrm{P}_{\mathrm{o}}$ in peat soils (Table 1). The mean proportion of $\mathrm{P}_{\mathrm{o}}$ in the $\mathrm{H}_{2} \mathrm{SO}_{4}-\mathrm{P}$ fraction in three drained Histosols was $7 \%$ of the total $\mathrm{P}$, whereas that of mean for three rewetted peatlands was $11 \%$ of total $\mathrm{P}$ as $\mathrm{P}_{\mathrm{o}}$ (Table 1 ). However, regardless of the abundance of $\mathrm{P}_{\mathrm{i}}$ or $\mathrm{P}_{\mathrm{O}}$, the $\mathrm{H}_{2} \mathrm{SO}_{4}-\mathrm{P}$ fraction is stable and contributes less to soluble and mobile $\mathrm{P}$ in the short term.

The higher labile and moderately labile $P$ fractions in the drained peatlands than that of the rewetted peatlands of the present study clearly indicated the $P$ fractions could easily be released upon mechanical disturbance of the drained peatlands. Furthermore, not only drainage but also the current land uses and management practices could influence $P$ transformation and distribution. Soils subjected to continuous cultivation and fertilization could be more dangerous than the drained peatlands used as grasslands. For example, the relative proportion of easily exchangeable P (AEM-P) in Luvisols, Alisols, and Histosols (Figure 4) could more easily contribute to freshwater eutrophication than the drained peatlands of the present study. Thus, not only drainage and rewetting but also current land use and management practices, accessibility to a waterbody, and topographic position could determine whether a peatland is a sink or a source of $P$. 


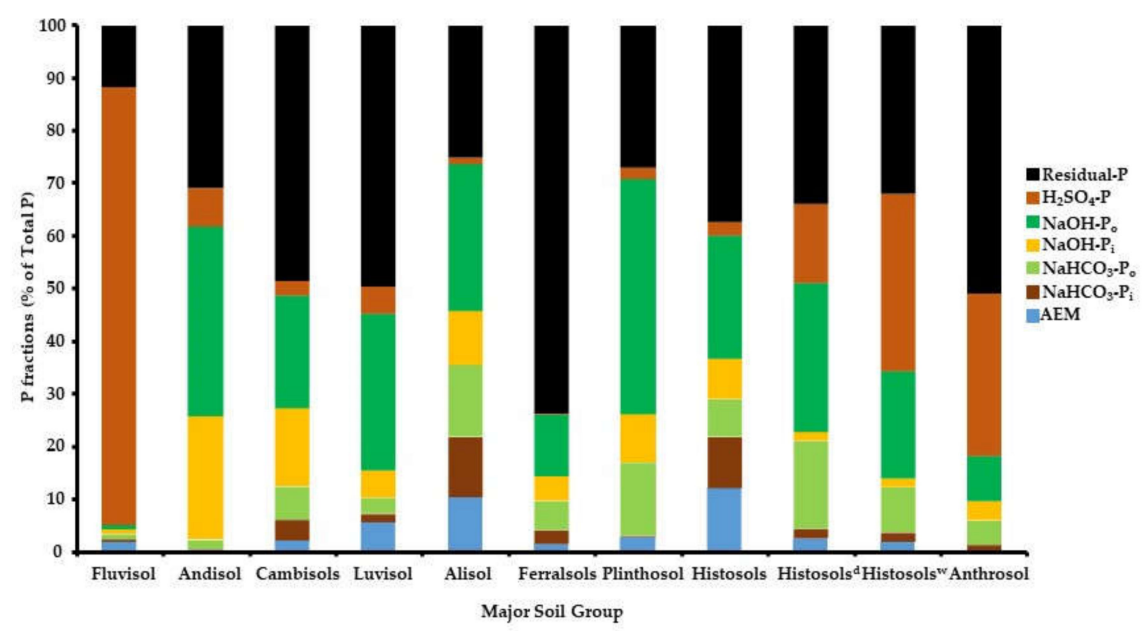

Figure 4. Proportions of different $P$ fractions in some major soil groups and the present study (Histosols ${ }^{d}$ and Histosls ${ }^{\mathrm{w}}$ ). Some of the major groups were the means of more than two studies. Data compiled for this figure derived from the control of each study with no manure and fertilizer application in the reported study if any. We summed to residual any $\mathrm{P}$ fraction determined after the fourth $\mathrm{P}$ fraction i.e., after $1 \mathrm{M} \mathrm{HCl}$ or $1 \mathrm{M} \mathrm{H}_{2} \mathrm{SO}_{4}$ extraction. Histosols ${ }^{\mathrm{d}}$ and Histosls ${ }^{\mathrm{w}}$ : means of the three drained and three rewetted peatlands of the present study, respectively. Sources: [46-58].

Overall, the results of the present study showed that the response of $\mathrm{P}$ to drainage and rewetting depend on the predominant $P$ fractions and biogeochemistry of the studied soils in addition to management practices. For example, rewetting increased the $\mathrm{P}$ stability when the predominant $\mathrm{P}$ fraction was $P_{o}$ and drainage increased $P_{o}$ oxidation regardless of soil types $[59,60]$. On the other hand, long-term rewetting mineral soils increased $P$ release and decreased the degree of $P$ saturation $[61,62]$. However, another study reported that drainage increased the maximum P sorption capacity of Cambisol in simulated alternating drainage-rewetting experiment [63]. Such contrasting results can be attributed to variations in the experimental approaches, anthropological factors, and topographic positions. This unequivocally indicates drainage and rewetting cycles can differently influence $P$ dynamics in different soil types. Thus, knowing different $P_{o}$ and $P_{i}$ fractions and soil biogeochemistry can help to understand the influence of drainage and rewetting on $P$ dynamics in a given soil.

\subsection{Solution ${ }^{31} P$ NMR and $P$ K-XANES}

The P species identified by the solution ${ }^{31} \mathrm{P}$ NMR analysis agreed with the results of similar studies conducted on agriculturally influenced European peat soils [64]. The predominance of $\alpha$ - and $\beta$-glycerol phosphates species in the ${ }^{31} \mathrm{P}$ NMR analysis (Figure 3 and Table 5 ) can be attributed to the hydrolysis of orthophosphate diesters during the alkaline extraction [65]. However, in the ${ }^{31} \mathrm{P}$ NMR analysis, the IHP was the second to the glycerol phosphates (Table 5), indicating that $\mathrm{P}_{\mathrm{o}}$ in the peat soils was part of structural components of the partially decomposed peats. This is not surprising since the studied peats were partially decomposed with the high C-content [21] that was similar to that of the undecomposed plant materials. A similar study conducted on peatlands of diverse organic matter content also indicated that the IPH abundance was directly proportional to the mineral contents and inversely proportional to soil organic matter content [42].

The lower proportion of $\mathrm{P}_{\mathrm{O}}$ recovered by solution ${ }^{31} \mathrm{P}$ NMR than $\mathrm{P}_{\mathrm{O}}$ recovered by sequential $\mathrm{P}$ fractionation, $\mathrm{NaOH}$-EDTA, and ignition methods can be attributed to the high concentration of $\mathrm{Fe}$ in the NaOH-EDTA extracts (Table 4). The high Fe concentration (1.09 to $26.09 \mathrm{~g} \mathrm{~kg}^{-1}$ ) recovered by the NaOH-EDTA extraction can hinder P speciation by the solution ${ }^{31} \mathrm{P}$ NMR since Fe is known to disturb NMR spectra quality in soil and environmental samples due to line broadening and increasing signal relaxation rates [66]. For instance, the concentration of Fe was the highest in the rewetted forest 
peatland where the weak signal to noise ratio made it difficult to identify the peaks of orthophosphate monoesters and diesters in this sample (Figure 2b).

In the present study, the P K-XANES analysis was able to distinguish $\mathrm{P}_{\mathrm{o}}$ from $\mathrm{P}_{\mathrm{i}}$ species; however, it failed to identify different $P_{0}$ species since all $P_{o}$ species were identified as if it were IHP (Table 6). This agreed with the recent conclusion derived from a review of many previous studies where only two to five chemical species of $\mathrm{P}$ can be identified using one of spectroscopic techniques such as XANES and NMR [67]. The authors also emphasized the matrix complexity of the soil and environmental samples increased the uncertainty in chemical P speciation by most of the spectroscopic techniques. However, the relative proportion of $P_{i}$ species detected by the XANES analysis at the surface horizons of most sites (Table 6) was similar to the sequential P fractionation and NaOH-EDTA methods (Tables 1 and 3). This is in line with the results of previous studies that indicated XANES is more suitable for $P$ speciation in minerals and crystalline compounds than $P_{o}$ species [67-69].

\subsection{Synthesis}

Among the analytical techniques used, the sequential P fractionation method clearly demonstrated the influence of drainage and rewetting on P speciation (Figure 1, Table 1). Although this method has not been used widely for P speciation in peat soils, two global reviews showed that the method can distinguish the impact of soil formation [44] and different land uses and management practices on $\mathrm{P}$ dynamics in minerals soils of temperate, tropical, and subtropical climates [15]. Furthermore, rewetting increased the absolute concentration and relative proportions of $\mathrm{H}_{2} \mathrm{SO}_{4}-\mathrm{P}$ and residual-P (Table 1 and Figure 2), which was resistant to extraction by the strong chemicals. Therefore, rewetting degraded peatlands are not an option but a must to lock up P in soil organic matter and transform labile $P$ to stable $P$ forms.

The results of ${ }^{31} \mathrm{P}$ NMR and P K-XANES analyses indicated that $\mathrm{P}_{\mathrm{o}}$ was the predominant $\mathrm{P}$ species; however, each of the spectroscopic analysis did not decipher the influence of long-term drainage and rewetting on $\mathrm{P}$ speciation. Furthermore, degradation of labile $\mathrm{P}_{\mathrm{o}}$ species during alkaline extraction, high concentration of $\mathrm{Fe}$ and organic matter in the extracts were the challenges during the NMR analysis. The addition of $\mathrm{Na}_{2} \mathrm{~S} .9 \mathrm{H}_{2} \mathrm{SO}_{4}$, supposed to reduce Fe concentration [30], improved the spectra quality in samples with relatively low Fe content (Table 4 and Figure 2f), but it did not solve the problem for samples with the high Fe content. The high organic matter [21] contributed to high viscosity but the recommended further diluting resulted in the disappearing of peaks from NMR spectra, especially for samples with the low $P$ content. The XANES analysis was able to distinguish $P_{o}$ and $P_{i}$ but it was not sensitive enough in distinguishing the impact of drainage and rewetting on $P$ speciation in the studied peat soils.

The abrupt change of total $P$ from the surface $(0-20 \mathrm{~cm}$ soil depths) to subsurface horizons $(20-80 \mathrm{~cm}$ soil depths) (Table S1) clearly indicated that $\mathrm{P}$ accumulation at the surface horizons originated from relatively recent history since intensive use of chemical $P$ fertilizers have started in the mid-20th century in Germany and elsewhere [70]. The significant differences in total $P$ at the surface horizons of different peatlands can be attributed to variations in $P$ inputs and outputs. However, the significant variations in the distribution of different $P$ fractions could be due to biogeochemical processes in addition to $P$ inputs and outputs to and from the soils. For instance, the distribution of $\mathrm{P}$ fractions can change under aerobic-anaerobic conditions [71]. Furthermore, the relative proportion of mineral and organic matter in the horizons influenced the absolute and relative proportion of different $\mathrm{P}$ fractions recovered by sequential $\mathrm{P}$ fractionation, ignition, and $\mathrm{NaOH}$-EDTA methods (Tables 1-3 and Figure 2). Differences in soil organic matter can explain the higher relative proportion of stable $\mathrm{P}$ fractions in the percolation mires than in the costal and drained forest peatlands (Figure 2). The higher proportions of stable $P$ fractions with depths also agreed with the higher soil organic matter content in the subsurface horizons of the percolation mires [21].

Many previous studies reported that rewetting increased P solubility and mobility in soils $[13,14,40]$. These studies, however, investigated the effect of anaerobic conditions on degraded fen peat that was 
previously P-enriched by fertilization. The results of the present study described systems in which new peat has been formed under the influence of longer-term rewetting. In this situation, it is plausible that $\mathrm{P}$ was incorporated into stable, mostly organic compounds, in the long-term rewetted peatlands.

\section{Conclusions}

Both the traditional wet chemical and spectroscopic analyses showed that the predominant $\mathrm{P}$ species in the studied peatlands was $\mathrm{P}_{\mathrm{o}}$. However, only the sequential $\mathrm{P}$ fractionation revealed the influence of drainage and rewetting on P-distribution and P-transformation in different peatland types. Accordingly, the absolute and relative proportions of $\mathrm{P}_{\mathrm{o}}$ and residual-P increased with rewetting, indicating that long-term rewetting increased $P$ sequestration in newly formed peat. Therefore, the key issue for the fate of $\mathrm{P}$ under rewetting is the formation of peat that stabilizes $\mathrm{P}$. This view is confirmed by increases in the relative proportions of stable P from the surface to subsurface horizons regardless of differences in absolute P content, management practices, and peatland types. Since the subsurface horizons were water-saturated in most seasons of the year. Any biochemical transformations of $P$ in the subsurface horizons are much lower than in the surface horizons because of fluctuations in the redox status in the later depending on seasons. Therefore, drainage and rewetting influenced P species only in the top $0-20 \mathrm{~cm}$ soil depths. Thus, relative proportions of different $\mathrm{P}$ fractions, duration of drainage and rewetting, peatland types, and current land systems need to be considered to predict the ecological and economic impact of $\mathrm{P}$ due to any peatland management practice.

Supplementary Materials: The following are available online at http://www.mdpi.com/2571-8789/4/1/11/s1: Table S1: Concentration of the selected total elements in different peatlands, Table S2: Concentration of different phosphorus fractions in some major soil groups and the present study.

Author Contributions: W.N.: conceptualization, investigation, data curation, formal analysis, writing original draft preparation, D.M.: NMR. analysis, W.K.: XANES analysis; P.L.: conceptualization, funding acquisition, writing-review and editing. All authors have read and agreed to the published version of the manuscript.

Funding: The European Social Fund (ESF) and the Ministry of Education, Science and Culture of Mecklenburg-Western Pomerania funded this work within the scope of the project WETSCAPES (ESF/14-BM-A55-0029/16-64160025). Furthermore, this work contributes to the scopes of the Leibniz-ScienceCampus "Phosphorus Research Rostock".

Acknowledgments: The authors highly appreciated the assistance received from Elena Heilmann and Christoph Jahnke, Soil Science Laboratory, University of Rostock, and Heike Borgwaldt NMR Laboratory at the University of Rostock. J. Prietzel, TU Munich, is highly acknowledged for providing the spectra of the reference compounds. The authors were also grateful for support they received from the BL8 staff of Synchrotron Light Research Institute. This work was done within the scope of the Leibniz-ScienceCampus "Phosphorus Research Rostock".

Conflicts of Interest: The authors declare no conflict of interest.

\section{References}

1. Reddy, K.R.; DeLaune, R.D. Biogeochemistry of Wetlands: Science and Applications; Taylor and Francis Group: New York, NY, USA, 2008.

2. Joosten, H. European mires: A preliminary status report. Int. Mire Conserv. Group Memb. Newsl. 1997, 3, $10-13$.

3. Lamers, L.P.M.; Vile, M.A.; Grootjans, A.P.; Acreman, M.C.; van Diggelen, R.; Evans, M.G.; Richardson, C.J.; Rochefort, L.; Kooijman, A.M.; Roelofs, J.G.M.; et al. Ecological restoration of rich fens in Europe and North America: From trial and error to an evidence-based approach. Biol. Rev. 2015, 90, 182-203. [CrossRef]

4. Paer, H.W. Controlling eutrophication along the freshwater-marine continuum: Dual nutrient $(\mathrm{N}$ and $\mathrm{P})$ reductions are essential. Estuar. Coast. 2009, 32, 593-601. [CrossRef]

5. Andersen, R.; Wells, C.; Macrae, M.; Price, J. Nutrient mineralisation and microbial functional diversity in a restored bog approach natural conditions 10 years post restoration. Soil Biol. Biochem. 2013, 64, 37-47. [CrossRef]

6. Zak, D.; Gelbrecht, J.; Wagner, C.; Steinberg, C.E.W. Evaluation of phosphorus mobilization potential in rewetted fens by an improved sequential chemical extraction procedure. Eur. J. Soil Sci. 2008, 59, 1191-1201. [CrossRef] 
7. Forsmann, D.M.; Kjaergaard, C. Phosphorus release from anaerobic peat soils during convective discharge-Effect of soil Fe: P molar ratio and preferential flow. Geoderma 2014, 223-225, 21-32. [CrossRef]

8. Shen, J.; Yuan, L.; Zhang, J.; Li, H.; Bai, Z.; Chen, X.; Zhang, W.; Zhang, F. Phosphorus dynamics: From Soil to Plant. Plant Physiol. 2011, 156, 997-1005. [CrossRef] [PubMed]

9. Penn, C.J.; Camberato, J.J. A critical review on soil chemical processes that control how soil pH affects phosphorus availability to plants. Agriculture 2019, 9, 120. [CrossRef]

10. Dunne, E.J.; Reddy, K.R. Phosphorus biogeochemistry of wetlands in agricultural watersheds. In Nutrient Management in Agricultural Watersheds: A Wetlands Solution; Dunne, E.J., Reddy, K.R., Carton, O.T., Eds.; Wageningen Academic Publishers: Cambridge, MA, USA, 2005.

11. Linquist, B.A.; Ruark, M.D.; Hill, J.E. Soil order and management practices control soil phosphorus fractions in managed wetland ecosystems. Nutr. Cycl. Agroecosyst. 2011, 90, 51-62. [CrossRef]

12. Tuukkanen, T.; Marttila1, H.; Kløve, B. Predicting organic matter, nitrogen, and phosphorus concentrations in runoff from peat extraction sites using partial least squares regression. Water Resour. Res. 2017, 53, 5860-5876. [CrossRef]

13. Zak, D.; Gelbrecht, J.; Steinberg, C.E.W. Phosphorus retention at the redox interface of peatlands adjacent to surface waters in northeast Germany. Biogeochemistry 2004, 70, 357-368. [CrossRef]

14. Kjaergaard, C.; Heiberg, L.; Jensen, H.S.; Hansen, H.C.B. Phosphorus mobilization in rewetted peat and sand at variable flow rate and redox regimes. Geoderma 2012, 173-174, 311-321. [CrossRef]

15. Negassa, W.; Leinweber, P. How does the Hedley sequential phosphorus fractionation reflect impacts of land use and management on soil phosphorus: A review? J. Plant Nutr. Soil Sci. 2009, 172, 305-325. [CrossRef]

16. Pierzynski, G.M.; McDowell, R.W.; Sims, J.T. Chemistry, Cycling, and Potential Movement of Inorganic Phosphorus in Soils. In Phosphorus: Agriculture and the Environment; Sims, J.T., Sharpley, A.S., Eds.; Agronomy Monograph 46; Agronomy Society of America, Crop Science Society of America, and Soil Science Society of America: Madison, WI, USA, 2005.

17. Forster, J. Peatlands Restoration in Germany-A Potential Win-Win-Win Solution for Climate Protection, Biodiversity Conservation and Land Use. Available online: https://www.teebweb.org (accessed on 6 January 2020).

18. Zerbe, S.; Steffenhagen, P.; Parakenings, K.; Timmermann, T.; Frick, A.; Gelbrecht, J.; Zak, D. Ecosystem Service Restoration after 10 Years of Rewetting Peatlands in NE Germany. Environ. Manag. 2013, 51, 1194-1209. [CrossRef] [PubMed]

19. Schlichting, A.; Leinweber, P.; Meissner, R.; Altermann, M. Sequentially extracted phosphorus fractions in peat derived soils. J. Plant Nutr. Soil Sci. 2002, 165, 290-298. [CrossRef]

20. Kruse, J.; Leinweber, P. Phosphorus in sequentially extracted fen peat soils: A K-edge X-ray absorption near-edge structure (XANES) spectroscopy study. J. Plant Nutr. Soil Sci. 2008, 171, 613-620. [CrossRef]

21. Negassa, W.; Acksel, A.; Eckhardt, K.-U.; Regier, T.; Leinweber, P. Soil organic matter characteristics in drained and rewetted peatlands of northern Germany: Chemical and spectroscopic analyses. Geoderma 2019, 353, 468-481. [CrossRef]

22. FAO (Food and Agricultural Organization of the United Nations). Guidelines for Soil Description; Food and Agriculture Organization of the United Nations: Rome, Italy, 2006.

23. IUSS Working Group WRB. World Reference Base for Soil Resources 2014, Update 2015 International Soil Classification System for Naming Soils and Creating Legends for Soil Maps; FAO: Roma, Italy, 2015.

24. Kuo, S. Phosphorus. In Methods of Soil Analysis Part 3: Chemical Methods; Sparks, D.L., Ed.; SSSA Book Series 5; Soil Science Society of America: Madison, WI, USA, 1996.

25. VdLUFA. Das VdLUFA Methodenbuch; VdLUFA Verlag: Darmstadt, Germany, 2012.

26. Tiessen, H.; Stewart, J.W.B.; Moir, J.O. Changes in organic and inorganic phosphorus composition of two grassland soils and their particle size fractions during 60-90 years of cultivation. J. Soil Sci. 1983, 34, 815-823. [CrossRef]

27. Murphy, J.; Riley, J.P. A modified single solution method for determination of phosphate in natural waters. Anal. Chim. Acta 1962, 27, 31-36. [CrossRef]

28. Tiessen, H.; Moir, J.O. Characterization of available P by sequential extraction. In Soil Sampling and Methods of Analysis, 2nd ed; Carter, M.R., Gregorich, E.G., Eds.; Taylor and Francis Group: Abingdon, UK, 2008.

29. Cade-Menun, B.J. Improved peak identification in ${ }^{31} \mathrm{P}-\mathrm{NMR}$ spectra of environmental samples with a standardized method and peak library. Geoderma 2015, 257-258, 102-114. [CrossRef] 
30. Vestergren, J.; Vincent, A.G.; Jansson, M.; Persson, P.; Ilstedt, U.; Gröbner, G.; Giesler, R.; Schleucher, J. High-resolution characterization of organic phosphorus in soil extracts using $2 \mathrm{D}^{1} \mathrm{H}-{ }^{31} \mathrm{P}$ NMR correlation spectroscopy. Environ. Sci. Technol. 2012, 46, 3950-3956. [CrossRef] [PubMed]

31. Prietzel, J.; Harrington, G.; Häusler, W.; Heister, K.; Werner, F.; Klysubun, W. Reference spectra of important adsorbed organic and inorganic phosphate binding forms for soil P speciation using synchrotron-based K-edge XANES spectroscopy. J. Synchrotron Rad. 2016. [CrossRef]

32. Ravel, B.; Newville, M. ATHENA, ARTEMIS, HEPHAESTUS: Data analysis for X-ray absorption spectroscopy using IFEFFIT. J. Synchrotron Rad. 2005, 12, 537-541. [CrossRef] [PubMed]

33. SAS. Cary, NC: SAS Institute Inc. Version 9. Available online: https://support.sas.com/documentation/ onlinedoc/91pdf/sasdoc_91/stat_ug_7313.pdf (accessed on 5 February 2020).

34. Brünger, A.T. Free R value: A novel statistical quantity for assessing the accuracy of crystal structures. Nature 1992, 355, 472-475. [CrossRef] [PubMed]

35. Pombal, X.P.; Muñoz, J.C.N.; Cortizas, A.M. Peat. In Encyclopedia of Soil Science; Chesworth, W., Ed.; Springer: Berlin/Heidelberg, Germany, 2008.

36. Rezanezhad, F.; Price, J.S.; Quinton, W.L.; Lennartz, B.; Milojevic, T.; Cappellen, P.V. Structure of peat soils and implications for water storage, flow and solute transport: A review update for geochemists. Chem. Geol. 2016, 429, 75-84. [CrossRef]

37. Bedrock, C.N.; Cheshire, M.V.; Shand, C.A. The involvement of iron and aluminum in the bonding of phosphorus to soil humic acid. Commun. Soil Sci. Plant Anal. 1997, 28, 961-971. [CrossRef]

38. Jordan, S.; Velty, S.; Zeitz, J. The influence of degree of peat decomposition on phosphorus binding forms in fens. Mires Peat 2007, 2, 1-10.

39. Callery, O.; Brennan, R.B.; Healy, M.G. Use of amendments in a peat soil to reduce phosphorus losses from forestry operations. Ecol. Eng. 2015, 85, 193-200. [CrossRef]

40. Riddle, M.; Bergström, L.; Schmieder, F.; Kirchmann, H.; Condron, L.; Aronsson, H. Phosphorus leaching from an organic and a mineral arable soil in a rainfall simulation study. J. Environ. Qual. 2018, 47, 487-495. [CrossRef]

41. Zak, D.; Wagner, C.; Payer, B.; Augustin, J.; Gelbrecht, J. Phosphorus mobilization in rewetted fens: The effect of altered peat properties and implications for their restoration. Ecol. Appl. 2010, 20, 1336-1349. [CrossRef]

42. Cheesman, A.W.; Turner, B.L.; Reddy, K.R. Forms of organic phosphorus in wetland soils. Biogeosciences 2014, 11, 6697-6710. [CrossRef]

43. Hou, E.; Chen, C.; Kuang, Y.; Zhang, Y.; Heenan, M.; Wen, D. A structural equation model analysis of phosphorus transformations in global unfertilized and uncultivated soils. Glob. Biogeochem. Cycles 2016, 30, 1300-1309. [CrossRef]

44. Cross, A.F.; Schlesinger, W.H. A literature review and evaluation of the Hedley fractionation: Applications to the biogeochemical cycle of soil phosphorus in natural ecosystems. Geoderma 1995, 64, 197-214. [CrossRef]

45. Yang, X.; Post, W.M. Phosphorus transformations as a function of pedogenesis: A synthesis of soil phosphorus data using Hedley fractionation method. Biogeosciences 2011, 8, 2907-2916. [CrossRef]

46. Xu, G.; Shao, H.-B.; Sun, J.-N.; Chang, S.X. Phosphorus fractions and profile distribution in newly formed wetland soils along a salinity gradient in the Yellow River Delta in China. J. Plant Nutr. Soil Sci. 2012, 175, 721-728. [CrossRef]

47. Redel, Y.; Staunton, S.; Durán, P.; Gianfreda, L.; Rumpe, C.; Mora, M.L. Fertilizer P Uptake Determined by Soil P Fractionation and Phosphatase Activity. J. Soil Sci. Plant. Nut. 2019. [CrossRef]

48. Ahmed, W.; Jing, H.; Kaillou, L.; Qaswar, M.; Khan, M.N.; Jin, C. Changes in phosphorus fractions associated with soil chemical properties under long-term organic and inorganic fertilization in paddy soils of southern China. PLoS ONE 2019, 14, e0216881. [CrossRef]

49. Pätzold, S.; Hejcman, M.; Barej, J.; Schellberg, J. Soil phosphorus fractions after seven decades of fertilizer application in the Rengen Grassland Experiment. J. Plant Nutr. Soil Sci. 2013, 176, 910-920. [CrossRef]

50. Crews, T.E.; Brookes, P.C. Changes in soil phosphorus forms through time in perennial versus annual agroecosystems. Agri. Ecosyst. Environ. 2014, 184, 168-181. [CrossRef]

51. Jien, S.-H.; Baillie, I.; Hu, C.-C.; Chen, T.-H.; Iizuka, Y.; Chiu, C.-Y. Forms and distribution of phosphorus in a placic podzolic toposequence in a subtropical subalpine forest, Taiwan. Catena 2016, 140, 145-154. [CrossRef] 
52. Rocha, J.H.T.; Menegale, M.L.C.; Rodrigues, M.; Gonçalves, J.L.M.; Pavinato, P.S.; Foltran, E.C. Impacts of timber harvest intensity and P fertilizer application on soil P Fractions. Forest Ecol. Manag. 2019, 437, $295-303$. [CrossRef]

53. Soltangheisi, A.; de Moraes, M.T.; Cherubin, M.R.; Alvarez, D.O.; de Souza, L.F.; Bieluczyk, W. Forest conversion to pasture affects soil phosphorus dynamics and nutritional status in Brazilian Amazon. Soil Till. Res. 2019, 194, 104330. [CrossRef]

54. Foltran, E.C.; Rocha, J.H.T.; Bazani, J.H.; Goncalves, J.L.M.; Rodrigues, M.; Pavinato, P. Phosphorus pool responses under different $\mathrm{P}$ inorganic fertilizers for a eucalyptus plantation in a loamy Oxisol. For. Ecol. Manag. 2019, 435, 170-179. [CrossRef]

55. Von Sperber, C.; Stallforth, R.; Preez, C.D.; Amelung, W. Changes in soil phosphorus pools during prolonged arable cropping in semiarid grasslands. Eur. J. Soil Sci. 2017, 68, 462-471. [CrossRef]

56. Parent, L.E.; Parent, S.-É.; Ziadi, N. Biogeochemistry of soil inorganic and organic phosphorus: A compositional analysis with balances. J. Geochem. Explor. 2014, 141, 52-60. [CrossRef]

57. Wang, G.; Bao, K.; Yu, X.; Zhao, H.; Lin, Q.; Lu, X. Forms and accumulation of soil P in a subalpine peatland of Mt. Changbai in Northeast China. Catena 2012, 92, 22-29. [CrossRef]

58. Mao, X.; Xu, X.; Lu, K.; Gielen, G.; Luo, J.; He, L. Effect of 17 years of organic and inorganic fertilizer applications on soil phosphorus dynamics in a rice-wheat rotation cropping system in eastern China. J. Soils Sediments 2015. [CrossRef]

59. Dieter, D.; Herzog, C.; Hupfer, M. Effects of drying on phosphorus uptake in re-flooded lake sediments. Environ. Sci. Pollut. Res. 2015. [CrossRef]

60. Moustafa, M.Z.; Whiteb, J.R.; Coghlan, C.C.; Reddy, K.R. Influence of hydropattern and vegetation on phosphorus reduction in a constructed wetland under high and low mass loading rates. Ecol. Eng. 2012, 42, 134-145. [CrossRef]

61. Wang, C.; Fang, F.; Yuan, Z.; Zhang, R.; Zhang, W.; Guo, J. Spatial variations of soil phosphorus forms and the risks of phosphorus release in the water-level fluctuation zone in a tributary of the Three Gorges Reservoir. Sci. Total Environ. 2020, 699, 134124. [CrossRef]

62. Rahutomo, S.; Kovar, J.L.; Thompson, M.L. Phosphorus transformations in stream bank sediments in Iowa, USA, at varying redox potentials. J. Soil Sediment. 2018. [CrossRef]

63. Ma, L.; Yang, P.; Zhou, J.; Sun, X. Spatial distribution and release of phosphorus in purple soils in the water fluctuation zone of the Three Gorges Reservoir. JFAE 2014, 12, 1110-1117.

64. Bedrock, C.N.; Cheshire, M.V.; Chudek, J.A.; Goodman, B.A.; Shand, C.A. Use of ${ }^{31}$ P NMR to study the forms of phosphorus in peat soils. Sci. Total Environ. 1994, 152, 1-8. [CrossRef]

65. Vincent, A.G.; Vestergren, J.; Gröbner, G.; Persson, P.; Schleucher, J.; Giesler, R. Soil organic phosphorus transformations in a boreal forest chronosequence. Plant Soil 2013, 367, 149-162. [CrossRef]

66. Cade-Menun, B.; Liu, C.W. Solution Phosphorus-31 Nuclear Magnetic Resonance Spectroscopy of Soils from 2005 to 2013: A Review of Sample Preparation and Experimental Parameters. Soil Sci. Soc. Am. J. 2013, 78, 19-37. [CrossRef]

67. Kizewski, F.; Liu, Y.-T.; Morris, A.; Hesterberg, D. Spectroscopic approaches for phosphorus speciation in soils and other environmental systems. J. Environ. Qual. 2011, 40, 751-766. [CrossRef]

68. Beauchemin, S.; Hesterberg, D.; Chou, J.; Beauchemin, M.; Simard, R.R.; Sayers, D.E. Speciation of phosphorus in phosphorus-enriched agricultural soils using X-ray absorption near edge structure spectroscopy and chemical fractionation. J. Environ. Qual. 2003, 32, 1809-1819. [CrossRef]

69. Kruse, J.; Abraham, M.; Amelung, W.; Baum, C.; Bol, R.; Kühn, O. Innovative methods in soil phosphorus research: A review. J. Plant Nutr. Soil Sci. 2015, 178, 43-88. [CrossRef]

70. Russel, D.A.; Williams, G.G. History of Chemical Fertilizer Development. Soil Sci. Soc. Am. J. 1977, 41, 260-265. [CrossRef]

71. Cui, H.; Ou, Y.; Wang, L.; Yan, B.; Han, L.; Li, Y. Change in the distribution of phosphorus fractions in aggregates under different land uses: A case in Sanjiang Plain, Northeast China. Int. J. Environ. Res. Public Health 2019, 16, 212. [CrossRef]

(C) 2020 by the authors. Licensee MDPI, Basel, Switzerland. This article is an open access article distributed under the terms and conditions of the Creative Commons Attribution (CC BY) license (http://creativecommons.org/licenses/by/4.0/). 